\title{
EL “CUENTO DEL BUEY QUE BRAMÓ”: ENTRE EL JUDAÍSMO RABÍNICO Y EL CRISTIANISMO MILITANTE*
}

\author{
Amparo Alba Cecilia y Carlos Sainz de la Maza \\ Universidad Complutense de Madrid \\ aalba@ucm.es; csmaza@filol.ucm.es
}

Les fables ne sont pas ce qu'elles semblent être;

Le plus simple animal nous y tient lieu de maître,

Une morale nue apporte de l'ennui:

Le conte fait passer le précepte avec lui.

En ces sortes de feinte il faut instruire et plaire,

Et conter pour conter me semble peu d'affaire ${ }^{1}$

Con el nombre de judaísmo rabínico o judaísmo clásico se denomina a la época comprendida entre la destrucción del Templo de Jerusalén, en el año 70 de nuestra era y el final de las Academias rabínicas de Babilonia en el s. XI. Sus protagonistas son los rabinos o maestros de la Ley, cuyas enseñanzas están recogidas en un inmenso corpus literario, conocido de manera convencional, como literatura rabínica ${ }^{2}$, que tiene como principales hitos, la Misná, codificación de la ley judía a partir de la Torá de Moisés, el Talmud, comentario y discusión en las Academias rabínicas sobre el alcance y pormenores de la Misná, y el Midrás ${ }^{3}$, comentario exegético de los libros bíblicos según el método denominado derás ${ }^{4}$.

${ }^{*}$ Este trabajo se encuadra dentro del proyecto de investigación Patrimonio cultural escrito de los judios de la Península Ibérica (FFI2008-01863).

${ }^{1}$ J. de La Fontaine, Fables, VI, I, París, Garnier-Flammarion, 1998.

${ }^{2}$ Aunque algunas obras recogen tradiciones más antiguas y otras vieron su redacción final bien entrada la Edad Media, podemos establecer el periodo que va desde el s. II (fecha de la redacción de la Misná) hasta el s. VIII, como el periodo creativo de la literatura rabínica.

${ }^{3}$ Citamos los textos rabínicos siguiendo la edición: The CD Rom Judaic Classics Library, Chicago, Institute for Computers in Jewish Life and Davka Corporation.

${ }^{4}$ Para los términos hebreos que aparecen en el texto, hemos optado por acercar su grafía a la fonética castellana, indicando, incluso, su acentuación. L. F. Girón Blanc, «Los Midrasim», en Historia de la 


\section{La Hagadá rabínica y su valoración como método exegético}

El riquísimo y variado material literario que compone estas obras es, básicamente, de dos tipos: legal y narrativo ${ }^{5}$. Tanto por su volumen como por su contenido, los textos legales, o Halajá, son la parte fundamental de la literatura rabínica: se ocupan de la transmisión e interpretación de la Ley y de su aplicación al momento presente ${ }^{6}$. Hagadá ${ }^{7}$, por su parte, es el nombre que recibe todo el material narrativo disperso por el Talmud y los distintos midrasim. Su principal función es la de servir a las intenciones exegéticas de los maestros rabínicos: apoyar o limitar el alcance de las leyes mediante el recurso a todo tipo de elementos narrativos en los que la sabiduría popular transmitida oralmente se percibe todavía: refranes populares, anécdotas personales, descripciones de hechos históricos o de personajes reales o de ficción, leyendas e incluso fábulas de animales, son adaptados al contexto académico de esta literatura.

Algunas sentencias dispersas por el Talmud parecen indicar que durante la época de los tannaítas ${ }^{8}$ todo este saber tradicional y profano, mencionado frecuentemente con los términos de maasé «suceso, cuento» o mashal «parábola, fábula», no era considerado como parte de la Hagadá, aunque era apreciado y utilizado por su valor didáctico:

Rabí Yojanán decía: Cuando R. Meír disertaba en público, un tercio era Halajá, un tercio, Hagadá y otro tercio consistía en parábolas (meshalim) ${ }^{9}$.

Entre los especialistas se ha extendido desde antiguo la formulación de la Hagadá en términos negativos: es Hagadá (narración) lo que no es Halajá (legislación); y a comienzos del s. XI, el hispanohebreo Semuel ha-Naguid definía la Hagadá como «todo comentario en el Talmud sobre cualquier tema que no sea precepto ${ }^{10} \gg$.

literatura hebrea y judia, ed. de G. Seijas, Madrid, Trotta, 2014, pp. 289-312.

${ }^{5}$ Algunos autores hablan claramente de géneros literarios; véase L. F. Girón Blanc «Literatura derásica», El Olivo 36 (1992), pp. 83-103.

${ }^{6} \mathrm{~L}$. Miralles, «Rabinismo y literatura rabínica», en Historia de la literatura hebrea y judia, ob. cit, p. 259.

${ }^{7}$ De acuerdo con J. Targarona, Diccionario Hebreo-Español, Barcelona, Riopiedras, 1995, lema הדגה: «narración, leyenda, cuento, mito, fábula, relato, dicho, refrán, anécdota».

${ }^{8}$ De tanná «repetir»; nombre dado a los maestros rabínicos cuyas enseñanzas fueron «repetidas» oralmente hasta ser puestas por escrito en la Misná. Vivieron en los dos primeros siglos de nuestra era.

${ }^{9}$ Sanh 38b. Véase G. Stemberger, El judaísmo clásico. Cultura e historia del periodo rabínico, Madrid, Trotta, 2009, p. 160. Para la distinción detallada entre mashal y maase, véase D. Stern, Parables in Midrash. Narratives and Exegesis in Rabbinic Literature, Cambridge, Mass y London, Harvard University Press, 1994, $2^{\text {a }}$ ed.

${ }^{10}$ En Mabó le-Talmud (Introducción al Talmud), que aparece impreso generalmente como apéndice 
El «precepto», la obligación religiosa contenida en la Halajá, puede resultar para la gente común, como todo código legislativo, difícil de comprender y árido de aplicar; la Hagadá, sin embargo, con sus relatos anecdóticos, legendarios e incluso humorísticos, fue capaz de transmitir al pueblo los valores ético-religiosos del judaísmo de una forma más adecuada a su comprensión, convirtiéndose así en el complemento necesario de la Halajá.

Sin embargo, entre los rabinos de época talmúdica no hay unanimidad a la hora de valorar la Hagadá y su valor normativo; junto a dichos que expresan su crítica contra la Hagadá y condenan expresamente su puesta por escrito: «aunque lo escrito sea bueno, se ha de cortar la mano que lo ha puesto por escrito» ${ }^{11}$, encontramos otros que la elogian como una forma más que válida de conocer a Dios: «Los intérpretes de la Hagadá dicen: si quieres conocer a aquel que hablo y el mundo se originó, estudia Hagadá» ${ }^{12}$. De ella se ocupan en el Talmud los sabios más importantes, como Rabí Meír o Rabí Yojanán ben Zakkay, del que cuentan que «sus estudios incluían la Torá, la Misná, la Guemará, la Halajá y la Hagadá $\rangle^{13}$.

Aunque el interés principal de los rabinos era el conocimiento de la Halajá, el Talmud de Jerusalén recoge noticias de la existencia, en las Academias rabínicas de Galilea, de grupos de rabinos interesados especialmente en el género hagádico, a los que se refiere con el nombre de Rabbanan de-aggadeta, o rabinos hagadistas. La Hagadá, no obstante, tenía también sus detractores, como Rabí Zeíra, que calificaba a los hagadistas de «escribas hechiceros» y tachaba sus interpretaciones de heterodoxas e inútiles, pues no hacían más que «dar vueltas a los textos sin deducir nada ${ }^{14} »$.

Esta ambigüedad en la valoración de la Hagadá tuvo consecuencias importantes en el momento en que la polémica antijudía decidió utilizarla para construir sus argumentos, como se verá más abajo.

\subsection{El mashal y las fábulas de animales}

Uno de los modelos literarios propios de la Hagadá es el mashal, «una narración comparativa de carácter ejemplar que puede tomar los tonos de una

\footnotetext{
al primer tratado talmúdico. Vid. G. Stemberger, ob. cit., p. 159.

${ }^{11}$ En el tratado Sabbat del Talmud de Jerusalén, 16,1. (En adelante los tratados del Talmud se citarán por su nombre precedido de las iniciales TJ, para el Talmud de Jerusalén, y TB, para el de Babilonia)

${ }^{12}$ Sifré Deuteronomio $§ 49$.

${ }^{13}$ TB Babá Metsiá, 134a.

${ }^{14}$ TJ Maaserot 17b. Entre los hagadistas más destacados aquí están Rabí Jonatán, Rabí Samuel b. Najmán, o Rabí Tanjuma.
} 
fábula, un cuento o una alegoría» ${ }^{15}$; entre los muchos significados del término que recogen los diccionarios ${ }^{16}$, destacaremos el de «parábola, proverbio o fábula».

El mashal no es, sin embargo, una invención rabínica; la Biblia se sirve de parábolas, como la que utiliza el profeta Natán para hacer comprender al rey David la maldad de su acción (2 Sam 12,1-5), y de proverbios, como los que forman el libro atribuido al sabio rey Salomón: El Libro de los Proverbios (Sefer ha-Meshalim) de Salomón (Pr 1,1). En algunos de estos mesahlim bíblicos encontramos referencias a animales con un valor alegórico o ejemplar; algunos de ellos, como la burra del vidente Balaam (Núm 22) o el gran pez que se traga al profeta Jonás (Jon 2), desempeñan un papel protagonista en el relato bíblico como un instrumento del que se sirve Dios, en el caso de la burra, para proteger al pueblo de Israel de una maldición, y en el caso del gran pez para forzar al profeta a acatar la voluntad divina. Cuando el profeta Daniel es arrojado a la fosa de los leones, estos se abstienen de causarle ningún daño demostrando ante todos los paganos el poder protector de Dios (Dan 6). También encontramos, en el libro del profeta Ezequiel, una fábula protagonizada por dos grandes águilas que simbolizan la suerte que correrá la familia real (Ez 17, 3-12); el mismo valor alegórico se encuentra en la endecha sobre Sedecías, basada en la comparación de este rey con un cachorro de león criado por una leona y llevado con garfios a la tierra de Egipto (Ez 19). Las cualidades naturales de distintos animales sirven, en el libro de Proverbios, para enseñar al humano un comportamiento ejemplar: «Acude a la hormiga, holgazán; observa su proceder y aprende» $(\operatorname{Pr} 6,6-8$.$) ;$ de hormigas, damanes, langostas, lagartos y otros pequeños animales, se destaca su sabiduría ( $\operatorname{Pr} 30,24-28)$, mientras que el león, el gallo y el macho cabrío destacan por su aspecto señorial y su valor (Pr 30, 29-31).

Los rabinos utilizan el mashal para apoyar sus argumentos mediante una comparación de la que se puede extraer fácilmente una conclusión o una enseñanza moral. De ahí que sea frecuente encontrar en sus textos un aprecio por este género y una justificación de su empleo, como, por ejemplo, en el comentario al Cantar de los Cantares ${ }^{17}$ :

Por ello encuentras que hasta que Salomón surgió no se ponían ejemplos para explicar la Torá [...]. Así, de argumento en argumento y de parábola (mashal) en

${ }^{15}$ L. F. Girón, en Historia de la literatura hebrea y judía, ob. cit. p. 303.

${ }^{16}$ Ver J. Targarona, ob. cit., lema לשמ ל ל.

${ }^{17}$ Se trata del Midrás Rabbá al Cantar de los Cantares, comentario exegético al libro bíblico redactado hacia el 600 d.C. Citaremos las distintas obras que componen el Midrás Rabbá posponiendo Rabí a la referencia al libro bíblico correspondiente a cada comentario. 
parábola ${ }^{18}$ Salomón llegó a desvelar los secretos de la Torá, como está escrito: Proverbios de Salomón, hijo de David $(\operatorname{Pr} 1,1)[\ldots]$ Se parece a un rey en cuya casa desapareció una moneda de oro o una piedra preciosa ¿no es cierto que la podría encontrar con una mecha de escaso valor? Por lo mismo, no debe menospreciarse la parábola pues por medio de ella el hombre puede dominar los significados de la Torá. Y sabrás que esto es cierto porque Salomón, gracias a la parábola, dominó hasta los detalles más pequeños de la Torá ${ }^{19}$.

El variado material narrativo que los rabinos incorporaron a estas parábolas abarcaba desde leyendas populares de héroes nacionales -como patriarcas, profetas, o reyes bíblicos-, hasta mitos orientales sobre la creación del mundo o relatos fantásticos, ya fueran producto de la imaginación y tradición judías, o de tradiciones foráneas que se fueron judaizando a lo largo de los siglos. La cultura helenística, que fue penetrando en el judaísmo desde el siglo III a. C., puso al alcance de los maestros de la Ley los relatos protagonizados por animales existentes tanto en las fábulas de tradición esópica como en las colecciones de la India. Y, aunque los textos rabínicos reflejan, una vez más, la falta de unanimidad en cuanto a la consideración de estas fábulas, se han conservado unas treinta de ellas en el Talmud y el Midrás bajo la denominación de «fábulas de zorros» (Mishlé Shualim) ${ }^{20}$, aunque el zorro no sea el animal protagonista de todas ellas.

Entre los más afamados fabulistas rabínicos se encuentran, en el s. I de nuestra era, Hillel el Viejo, del que se afirma que comprendía «las conversaciones de los árboles y las nubes, y de las bestias y animales» ${ }^{21}, \mathrm{y}$ su discípulo, Yojanán ben Zakkay, entre cuyos conocimientos se mencionan «las analogías, la astronomía y la geometría, los proverbios de lavanderas y las fábulas de zorros; la lengua de los demonios, el susurro de las palmeras y el lenguaje de los ángeles servidores ${ }^{22}$. Rabí Aquiba se sirve de una fábula, protagonizada por el astuto y embaucador zorro que pretende engañar a unos peces, para animar a sus compañeros a desobedecer las prohibiciones romanas de predicar en público ${ }^{23}$. Pero ninguno como Rabí Meír, de mediados

\footnotetext{
${ }^{18}$ En el Libro de los Reyes se afirma que Salomón «compuso tres mil proverbios y mil cinco canciones y disertó sobre botánica [...] sobre cuadrúpedos y aves» (1Re 5, 12-13).

${ }^{19}$ Cant. R, 1.8. Trad. española de L. F. Girón Blanc, Midrás Cantar de los Cantares Rabbá, Estella, Verbo Divino, 1991, pp. 49-50. Maimónides insiste también en el valor exegético del mashal; véase su Guía de Perplejos, ed. de D. Gonzalo Maeso, Madrid, Trotta, 1994, p. 59.

${ }^{20}$ Adopta ese mismo nombre una conocida colección del s. XIII, editada por H. Schwarzbaum, The Mishle Shu'alim (Fox Fables) of Rabbi Berechiah Ha-Nakdan: A Study in Comparative Folklore and Fable Lore, Kiron (Israel), Institute for Jewish and Arab Folklore Research, 1979.

${ }^{21}$ TB Soferim, 16, 9.

${ }^{22}$ TB Baba Batra 134a y TB Sukká 28a.

${ }^{23}$ TB Berajot 61b.
} 
del s. II, del que se cuenta que conocía más de trescientas fábulas de zorros, aunque tres generaciones después, según la misma fuente, se conservaban sólo tres de ellas ${ }^{24}$. Según afirma la Misná, con su muerte desaparecieron los narradores de fábulas ${ }^{25}$.

Además de las fábulas esópicas, hay en la literatura rabínica muchos cuentos protagonizados por otros animales, como burros, bueyes o vacas, pacíficos animales de trabajo cuyas cualidades sirven como modelo de conducta humana. Así, el ejemplo de la vaca que respeta la costumbre de su amo judío de no trabajar en Sabbat, produce la conversión de su siguiente dueño, un gentil, que llegaría a ser el famoso rabino Yojanán bar Torta (literalmente «hijo de la vaca») $)^{26}$; y la burra de R. Pinjas ben Yaír preferirá morir de hambre a comer alimentos de los que no se hubiera apartado el diezmo sacerdota ${ }^{27}$. Del mismo estilo es el cuento que hemos seleccionado para este trabajo, el de un buey cuyos mugidos presagian la destrucción del Templo y el nacimiento del Mesías.

\section{El cuento del Buey que bramó en las fuentes hebreas}

Este cuento, que las fuentes castellanas designan también como «del árabo», es un ejemplo del aprovechamiento temprano de este material haggádico con fines morales y religiosos. Se encuentra recogido en dos fuentes rabínicas: en el tratado Berajot del Talmud de Jerusalén ${ }^{28}$ y en el Midrás Rabbá a Lamentaciones ${ }^{29}$, con algunas variantes. En estas fuentes, el cuento está integrado en una discusión más amplia sobre el verdadero nombre del Mesías: David, Tsemaj («vástago») o Menajem («consolador»). El relato viene a probar la opinión de Rabí Janina, de que todos los nombres son en realidad el mismo ya que tanto «Tsemaj» como «Menajem» tienen el mismo valor numérico ${ }^{30}$. La hagadá podría estar construida, adaptando probablemente materiales de origen folclórico, con la finalidad de ilustrar la secuencia de versículos de intención mesiánica Is 10,34 y 11, 1.

\footnotetext{
${ }^{24}$ TB Sanhedrín 39a.

${ }^{25}$ En el tratado misnaico Sotá, 9, 15.

${ }^{26}$ En Pesiqta Rabbati 14.

${ }^{27}$ Gén.R 60, 8.

${ }^{28} \mathrm{TJ}$ Berajot $17 \mathrm{~b}$.

${ }^{29}$ Lam.R 1, 51. La datación de esta obra puede remontarse al S. V; véase H. L. Strack y G. Stemberger, Introducción a la literatura talmúdica y midrásica, Estella, Verbo Divino, 2a ed., 1996, p. 384.

${ }^{30}$ La guematria, valor numérico de una palabra mediante el cálculo del valor de sus letras, es una técnica exegética rabínica que sirve para poner en relación distintas palabras con un mismo valor numérico. El valor numérico de Tsemaj y de Menajem, según la suma del valor de sus letras, es 138.
} 


\section{Talmud de Jerusalén, tratado Berajot $17 b$}

Esto lo prueba lo que dijo Rabí Yodán hijo de Rabí Aibo: Un judío estaba arando y su buey se puso a mugir lastimeramente; pasó un árabe y oyó el mugido; le dijo: «Hijo de judío, hijo de judío, suelta a tu buey y desata tu arado porque el templo ha sido destruido». Mugió (el buey) por segunda vez, y le dijo (el árabe): «Hijo de judío, hijo de judío: ata el buey y engancha el arado, porque ha nacido el rey Mesías». Le dijo: «¿Cuál es su nombre?». Respondió: «Menajem (Consolador)». «Y ¿cómo se llama su padre?». Le dijo: «Ezequías». Preguntó: «¿De dónde es?». Respondió: «De la ciudad real, de Belén de Judá».

Entonces vendió el buey y el arado y fue a comprar pañales de niño; iba pasando de pueblo en pueblo hasta que llegó a dicha ciudad. Todas las mujeres salieron a comprarle, pero la madre de Menajem no compraba nada. Oyó la voz de las mujeres que decían: «Madre de Menajem, madre de Menajem, ven a comprar para tu hijo». Dijo ella: «Preferiría ver estrangulados a los enemigos de Israel, pues el día en que yo di a luz, fue destruido el Templo». Le dijo (el vendedor): «Estamos seguros de que por su causa fue destruido y que por su causa será reconstruido». Ella le dijo: «No tengo dinero». Le dijo: «¿Y eso qué importa?, ven y cómpralo; si hoy no tienes, después de unos días yo vendré y te lo cobraré». Algunos días después volvió a aquella ciudad y le preguntó: «¿Qué ha pasado con tu niño?». Respondió: «Después de habernos visto vinieron vientos de tormenta y tempestades, y lo arrebataron de mis manos».

Dijo Rabí Abún: «¿Qué tenemos nosotros que aprender de este árabe? ¿No hay un versículo que dice: El Líbano por mano del Poderoso caerá? (Is 10,34); y sigue otro versículo: Y saldrá un brote del tocón de Jesé (Is 11,1)».

\section{Midrás Lamentaciones Rabbá 1,51}

A esto se refiere lo que dijo Rabí Yudán en nombre de Rabí Aibo: En una ocasión estaba un hombre arando y uno de sus bueyes mugió. Pasó por allí un árabe y le dijo: «¿Tú qué eres?» Respondió: «Soy judío». Le dijo: «Suelta tu buey y suelta el arado». Le preguntó: «¿Por qué?» Le respondió: «El Templo de los judíos ha sido destruido». Le volvió a preguntar: «¿Cómo lo sabes?». Respondió: «Lo he sabido por el mugido de tu buey». Mientras estaba entretenido con él, volvió a mugir el buey, y le dijo: «Unce a tu buey y ata el arado, porque ya ha nacido el libertador de los judíos». Le preguntó: «¿Cómo se llama?». Le dijo: «Menajem». «¿Y cómo se llama su padre?». Le respondió: «Ezequías». Le preguntó: «¿Y dónde vive?». Le respondió: «En Birat Arbá, en Belén de Judá».

Vendió aquel hombre su buey y su arado y fue a comprar pañales de niño. Fue de pueblo en pueblo y de ciudad en ciudad hasta que llegó a aquel lugar. Todos los habitantes iban a comprarle, pero la madre de ese niño no le compraba; le preguntó: «¿Por qué no compras pañales para el niño?». Ella le dijo: «Porque 


\section{A. Alba Cecilia y C. Sainz de la Maza}

un terrible destino le está reservado a mi niño». Él le preguntó: «¿Por qué?», y ella le dijo: «porque por su causa ha sido destruido el Templo»; él le dijo: «Nosotros confiamos en el Señor del mundo que por su causa ha caído el Templo y por su causa será reconstruido». Y añadió: «Tú quédate con algunos de estos pañales para tu niño, que yo volveré a tu casa dentro de unos días y cobraré la deuda». Ella cogió algunos y se fue. Unos días después dijo ese hombre: «Iré a ver qué ha sido de ese niño». Llegó junto a la mujer y le dijo: «¿Qué ha sido del niño?». Ella le respondió: «¿No te dije que tenía un destino terrible? De él mismo ha venido su desgracia. Desde aquel momento, vinieron vientos de tormenta y tempestades y se lo llevaron». Él le dijo: «¿Acaso no te dije que por su causa fue destruido y por su causa sería reconstruido?».

Dijo Rabí Abún: «¿Qué tengo yo que aprender de un árabe? ¿No hay un versículo completo que dice: Y el Líbano por mano del Poderoso caerá (Is 10,34) y dice a continuación: Pero saldrá un brote del tocón de Jesé (Is $11,1) ? »$.

El relato está mejor desarrollado, desde el punto de vista narrativo, en el texto midrásico, con una más cuidada articulación de los diálogos entre distintos personajes (árabe y judío; madre del Mesías y vendedor de pañales) que no se da en el texto talmúdico, aunque este añade la voz de las mujeres betlemitas que aporta un cierto encanto costumbrista ${ }^{31}$.

A pesar del importante papel del buey como elemento de arranque de la acción, el cuento no es una fábula animalística. El cuento da al buey una función de animal revelador inconsciente de verdades trascendentes parecida a la del zorro que, cruzando las ruinas del Templo, provoca la paradójica risa de Rabí Aquiba en el último cuento del midrás a Lamentaciones ${ }^{32}$.

En el Motif-Index elaborado por Dov $\mathrm{Noy}^{33}$ para la literatura talmúdicomidrásica, el cuento del buey daría expresión a los siguientes motivos: $\mathrm{B}$ : «Animales míticos», B154: «Animal oracular» y B154.1: «Buey oracular» (p. 218); Noy no incluye el ejemplo concreto del buey que anuncia al Mesías; podría haberlo hecho como una variante de B154+: «Animal mágico delata con ladridos o mugidos a un esclavo fugitivo». Y, por otra parte, V: «Religión», V296: «Mesías (como persona sagrada)» y V296+: «Nacimiento del Mesías en el día de la destrucción del Templo» (incluye aquí las referencias a nuestros

\footnotetext{
${ }^{31}$ Hace una comparación detallada de ambas versiones G. Hasan-Rokem, Web of Life. Folkore and Midrash in Rabbinic Literature, Stanford, Cal. Stanford University Press, 2000, pp. 152-160, donde subraya su carácter de híbrido entre leyenda y relato folclórico.

${ }^{32}$ Véase Lam.R. 5,18.

${ }^{33}$ D. Noy, Motif-Index of Talmudic-Midrasic Literature, (Tesis doct. Univ. Indiana), Bloomington, 1954, 2 vols.
} 
textos). Por las características de su segunda secuencia narrativa, se ha relacionado también con los esquemas míticos sobre el nacimiento del héroe ${ }^{34}$.

La hagadá no es tampoco un mashal en sentido estricto; está cercano a uno de los subtipos del maasé «histórico», aquel que centra el relato en el cumplimiento de determinadas profecías: «An anecdote is related concerning the fate of an individual, and at its conclusion a sage (or other person) "applies" (kara 'al) a verse to the occasion». La vida trivial del protagonista se ve, así, realzada por su convergencia con la autoridad de la Escritura ${ }^{35}$.

Por su énfasis en el contraste e íntima relación entre desesperación y esperanza mesiánica, ambas versiones del relato dan forma a un mismo intento de respuesta explicativa -en el sentido de una teodicea-a la situación de hundimiento generalizado en que se encontraba el judaísmo en los siglos inmediatamente posteriores a la destrucción del Templo (70 d.C.) y el ulterior, y definitivo, fracaso de la revuelta de Bar Kojba (132-135) ${ }^{36}$.

Al parecer, de este cuento existió también otra versión hebrea que no se ha conservado, en la que es el profeta Elías quien descubre la identidad del recién nacido. Pertenecería al comentario al libro bíblico de Génesis llamado Bereshit Rabba Rabbati (Génesis Rabbá Mayor), atribuido ${ }^{37}$ al talmudista y comentarista bíblico R. Moshe ha-Darshan, que vivió en Narbona a mediados del s. XI. De esta obra sólo se han conservado las hagadot que, con intención polémica, recogió Raimundo Martí en su Pugio Fidei (h. 1280) ${ }^{38}$.

El cuento del buey, según esta versión, reza como sigue:

Dice Rabí Samuel, hijo de Naamán: Caminaba en cierta ocasión Elías el mismo día de la destrucción del Templo, y oyó una voz celestial que le decía: «El Templo va a ser destruido». Al oír esto, Elías pensó que todo el mundo iba a ser destruido; y siguiendo su camino, se encontró a unos hombres que araban y sembraban, y les dijo: «El Señor está airado contra el mundo, y quiere destruir su casa y llevar cautivos a sus hijos entre las naciones, ¿y vosotros os preocupáis y

\footnotetext{
${ }^{34}$ G. Hasan-Rokem, ob. cit., p. 156.

${ }^{35}$ D. Stern, ob. cit., p. 246.

${ }^{36}$ Véase D. Stern, ob. cit., p. 3; G. Hasan-Rokem, ob. cit., p. 146.

${ }^{37}$ Los especialistas discrepan a la hora de dilucidar su autoría. A. Epstein, «Bereshit Rabbati», en Magazin für die Wissenschaft des Judenthums, vol. XV, piensa que el compilador del midrás es otro, que se ha inspirado en la obra Yesod de M. ha-Darshan. Sobre la polémica acerca del posible carácter ficticio de la obra, véase C. del Valle, La controversia judeocristiana en España (Desde los orígenes hasta el siglo XIII), Madrid, CSIC, 1998, p. 306.

${ }^{38}$ Para la edición de esos pasajes, véase J. Brierre-Narbonne, Bereshit Rabbá Rabbati de R. Moshe ha-Darshan, Paris, 1939. El Pugio se halla solo disponible en dos ediciones del s. XVII. Urge abordar críticamente la edición del texto a partir de sus numerosos manuscritos; véase R. Szpiech, «Citas árabes en caracteres hebreos en el Pugio Fidei del dominico Ramón Martí», en Al-Qantara XXXII (2011), pp. 71-107, esp. 76-80.
} 
trabajáis en las cosas temporales?» Y salió una voz celestial y le dijo: «Déjales, porque ha nacido el Salvador de Israel». Dijo él: «Y ¿dónde está?» Le respondió: «En Belén de Judá». Fue Elías y encontró a una mujer sentada en el umbral de su casa con su hijo ensangrentado echado ante ella. Dijo Elías: «Hija, ¿pariste un hijo?» Respondió ella: «Así es». Dijo Elías: «Y ¿qué le ocurre para yacer así ensangrentado?» Respondió la mujer: «Una gran desgracia, porque en el mismo día en que nació fue destruido el Templo». Y dijo Elías: «Ten paciencia y cuídale ya que por medio de él habrá una gran salvación».

La madre entonces, se rehizo y se ocupó de él. Elías la dejó y estuvo ausente cinco años.

Pasados los cinco años se dijo: «Iré y veré al Salvador de Israel, a ver si se está criando como un rey o como los ángeles servidores». Fue y encontró a la mujer de pie en el umbral de su casa, y le dijo: «Hija, ¿cómo está el niño? Respondió ella: «Rabí, ¿no te dije que era una desgracia criarlo? porque el mismo día en que nació fue destruido el Templo; y no solo esto, sino que tiene pies, pero no anda; ojos, pero no ve; oídos, pero no oye; boca, pero apenas habla, y ahí está como una piedra». Mientras así le hablaba, soplaron vientos desde los cuatro puntos cardinales, y se llevaron al niño al mar. Entonces Elías, rasgando sus vestiduras y mesándose los cabellos, dijo: «iAy, se ha perdido la salvación de Israel!» Salió una voz celestial y dijo: «Elías, no es como tú piensas, sino que vivirá en el mar durante cuatrocientos años, y durante ochenta, en el lugar al que sube el humo de los hijos de Corés ${ }^{39}$; pasará otros ochenta a la puerta de Roma, y los años restantes se repartirá entre todas las grandes ciudades, hasta que se cumpla su tiempo» ${ }^{40}$.

\footnotetext{
${ }^{39}$ Según Núm 16, Coré y sus secuaces fueron tragados vivos por la tierra como castigo por desempeñar funciones sacerdotales que no les correspondían, en un acto de rebelión contra Moisés y Aarón,

${ }^{40}$ Cf. Pugio Fidei, II c. VI: «Quod Messias Judaeorum secundum ipsos natus est illa die qua Templum destructum est a Tito et Vespasiano», pp. 350-351: "Dixit R. Samuel filius Nachman: Quadam vice erat Elias bonae memoriae ambulans per viam in ipsa die in qua domus Sanctuarii destructa est; audivitque Filiam vocis, id est arantes, et seminantes, et ait eis: "Sanctus benedictus iratus est contra saeculum suum, et vult destruere domum suam, et captivare filios suos inter gentes saeculi; et vos curatis, et estis solliciti de vita temporali " Egressa est Filia vocis, et dixit ei: "Dimitte illos, quia jam natus est Israeli Salvator". Dixit ei: "Et ubi est?". Ipsa dixit ei: "In Bethlehem Judae”. Ivit, et invenit mulierem sedentem in ostio domus suae, et filium ejus sanguine cruentatum jacentem coram ea. Dixit ipsi: "Filia mea, peperisti filium?". Quae dixit ei: "Etiam”. Ait ei: "Quid sibi vult quod jacet sic sanguine cruentatus?". Quae dixit ei: "Malum est maximum: ipsa namque die qua natus est destructa est domus Sanctuarii". Dixit ei: "Filia me constans esto, et curam illius habe, jam siquidem magna salus erit per manum ejus". Statim animata est, et curam ejus egit. Dimisit eum Elias, et abscessit quinque annis. Post quinque annos dixit: "Vadam, et videbo Salvatorem Israel, utrum sit in forma regum nutritio ejus, vel in forma Angelorum ministerii". Ivit, et invenit mulierem stantem in ostio domus suae; et ait: "Filia mea, in quo statu est puer ille?" Quae ait illi: "Rabbi, nonne dixi quod malum est nutrire ipsum?, quia in die qua natus est, destructa est domus Sanctuarii; nec solum hoc, sed pedes habet, et non ambulat; oculos, et non videt; aures, et non audit; os habet, et minime loquitur; et ecce jacet ut lapis. Adhuc eo (id est Elia) loquente flaverunt super eum venti a quattuor angulis mundi, duxeruntque eum ad mare magnum. Scidit Elias vestimenta sua, et depilavit capillos suos, et clamavit, ac dixit: "Vae! perdita est salus Israel”. Egressa est Filia vocis, et dixit: "Elia, non ita est, ut tu suspiceris; sed quadringentis annis morabitur in mari magno; et octoginta in ascensu
} 
En esta versión se elimina a los protagonistas principales del relato rabínico (judío, árabe y buey que brama). Parece que hay una racionalización de los aspectos fantásticos del relato (árabe y buey que interpretan los signos del Mesías). Elías, profeta y heraldo mesiánico, anuncia, con su presencia y de palabra, el nacimiento del Mesías.

\section{El cuento del buey en las obras de polémica}

En la literatura de polémica judeocristiana las hagadot rabínicas irrumpen con gran efectividad en las obras compuestas por judíos conversos. Por su repercusión, podemos considerar que el punto de partida es Pedro Alfonso de Huesca (Mosé Sefardí) y sus Dialogi contra Iudaeos (post. 1106). En estos primeros momentos las hagadot son el blanco principal de los ataques al judaísmo rabínico; Pedro Alfonso denuncia su falta de racionalidad lógica y científica, y lo herético de su contenido, que desvelan la falsedad del Talmud como Ley Oral de inspiración divina ${ }^{41}$.

Los Dialogi serán bien conocidos por todos los polemistas medievales ${ }^{42}$, y su vocación de denuncia de la irracionalidad del Talmud y el Midrás se mantendrá durante todo el periodo ${ }^{43}$. Sin embargo, en los siglos siguientes se añadirá una orientación nueva, que busca aprovechar las hagadot como testimonio positivo que refuerza la verdad del cristianismo frente al judaísmo. Tanto las controversias (Barcelona 1263, Tortosa 1413-14), como los tratados y summae de polémica (Pugio Fidei, Mostrador de Justicia) añadirán esta nueva orientación a la ya existente.

La «nueva polémica» cristiano judía bajomedieval, inspirada por los mendicantes y basada en planteamientos supuestamente racionales, pretendía asegurar la atención y hasta la aquiescencia del adversario tomando como

\footnotetext{
fumi apud filios Kore: et 80 in portis Romae, (et reliquo annorum reverteretur super omnes civitates magnas, usque ad tempus finis» (R. Martini, Pugio Fidei adversus mauros et judaeos, Lipsiae, Fridericus Lanckisius, 1687, pp. 350-351). Traduce también el texto, con alguna variante, A. Tostado en La Disputa de Barcelona de 1263. Controversia judeocristiana, Salamanca, Univ. Pontificia, 2009, pp. 211-212.

${ }^{41}$ Véase P. Alfonso de Huesca, Diálogo contra los judios, (Int. J. Tolan; texto lat. K-P. Mieth; trad. E. Ducay; coord. M. J. Lacarra) Huesca, Instituto de Estudios Altoaragoneses, 1996; J. Tolan, Petrus Alphonsi and his Medieval Readers, Gainesgille, FL, University Press of Florida, 1993, pp. 12-41, esp. 2225. Sobre su difusión medieval, pp. 95-131.

${ }^{42}$ Estarán, por ejemplo, en catalán, en la bien surtida biblioteca de Benedicto XIII, como alma de la controversia de Tortosa; véase J. Tolan, ob. cit., pp. 126-129; para su conocimiento en la Corona de Castilla, véase C. Sainz de la Maza, «De Pedro Alfonso a Abner-Alfonso: orto y cénit converso de la apologética antijudía medieval», en Dicenda, 15 (1997), pp. 271-288.

${ }^{43}$ La manifestación más llamativa de esta postura quizá sea el proceso antitalmúdico -con expurgo y quema de ejemplares incluido- que conocemos como Controversia de París (1240); véase J. Rosenthal, «The Talmud on Trial», en Jewish Quarterly Review, 47 (1956-57), pp. 58-76 y 145-169.
} 


\section{A. Alba Cecilia y C. Sainz de la Maza}

base para la argumentación únicamente los libros que este considerara como fuente legítima de doctrina. Así, y con la oportuna guía de conversos y frailes formados en estudios hebraicos, los cristianos ampliaron su arsenal de pruebas bíblicas con pasajes ad hoc tomados de la literatura rabínica y los comentaristas medievales, como Abraham ibn Ezra, Rashi o Maimónides ${ }^{44}$.

En este contexto se produce el aprovechamiento de relatos como el cuento del buey, cuya exégesis cristiana se aplicará a uno de los temas cruciales de la controversia cristiano-judía: la discusión sobre la venida y la identidad del Mesías. Como veremos más abajo, el debate en torno a este cuento cumple también un papel destacado en las discusiones sobre la autoridad doctrinal de los relatos hagádicos.

Examinaremos cómo aparece en lengua romance en el curso de las controversias públicas -Barcelona, 1263; Tortosa 1413-14- y los tratados de polémica con los que la Corona de Aragón se sumó a las campañas misioneras concebidas por los frailes mendicantes para acabar, por vías supuestamente racionales, con el problema judío. De la Corona de Castilla, más escasa en testimonios - prácticamente limitados a los escritos de Alfonso de Valladolid- pero peculiar en cuanto a la gestación y disposición de los mismos, nos ocuparemos en otro lugar.

Veremos a continuación qué función cumple nuestro cuento en relación con lo que podríamos llamar la poética del género polémico en sus dos formatos habituales: oral (controversias públicas) y escrito (tratadística) ${ }^{45}$.

\subsection{El cuento del buey en la Corona de Aragón}

La mayoría de los testimonios conservados están en castellano; sin embargo comenzaremos por la controversia de Barcelona, que se desarrolló en catalán, aunque la conocemos únicamente a través de escritos redactados en latín y hebreo.

\footnotetext{
${ }^{44}$ Véase C. Sainz de la Maza, «Literatura apologética y de polémica», en ed. de G. Seijas, ob. cit., pp. 575-596, esp. p. 588, y la bibliografía allí citada.

${ }^{45}$ Para las citas de textos medievales, seguiremos los siguientes criterios de transcripción: conservamos ç sólo ante a, o, u; modernizamos la distribución de las grafías $i / j$, $i / y$ (con excepción de los nombres propios) у $u / v$; distinguimos porque y por que ('para que' o 'por lo que'); mantenemos qu- ante a, o, pero no la ss en posición no intervocálica; transcribimos el signo tironiano como «e» y señalamos la $a$ embebida como «â»; puntuamos las frases, regularizamos el uso de mayúsculas, acentuamos las palabras y las separamos o unimos según el uso actual; indicamos las restauraciones evidentes con '[ ]' y las conjeturales con ' $<>$ '. Los corchetes cuadrados sirven también para indicar nuestras omisiones o el añadido de aclaraciones en los textos editados.
} 


\subsubsection{Controversia de Barcelona}

La primera aparición del cuento del buey que podemos documentar aunque indirectamente- en una lengua romance peninsular se produjo durante la sesión inaugural de la Controversia de Barcelona, organizada por los dominicos y celebrada en presencia de Jaime I de Aragón desde el 20 de julio al 8 de agosto de $1263^{46}$.

La revisión de los argumentos doctrinales que supuestamente probaban la verdad de las creencias cristianas enfrentó al dominico Fray Pablo Cristiano con el rabino gerundense Najmánides (Mosé ben Najmán), quizá el representante más ilustre del judaísmo tradicional de su época. La tensión generada durante las sesiones llevó al rey a suspenderlas a los pocos días de su inicio, pero en ese breve lapso de tiempo la discusión se centró precisamente en las circunstancias de la venida del Mesías, materializada para los cristianos en la figura histórica de Jesús de Nazaret (como redentor del pecado original y segunda persona de la Trinidad), y negada por los judíos, para quienes, además, nada tiene de divino ni de redentor de almas. ${ }^{47}$

Además de sus dos protagonistas, participaron puntualmente del debate algunos de los presentes como espectadores y jueces, y de modo destacado, el propio rey, quien no vaciló en pedir aclaraciones a Najmánides que este satisfizo con una familiaridad que delataba la buena relación existente entre ambos. La discusión tuvo, necesariamente, que desarrollarse en lengua vulgar -catalán, en este caso-, única común para todos los circunstantes. No es esta, sin embargo, la lengua de los documentos que dejaron constancia del acto.

Las mal llamadas «actas» latinas de la controversia no pasan de ser un resumen esquemático de lo expuesto en esos días por ambas partes, y en ellas no se menciona nuestro cuento. Este sí se transcribe en el Sefer ha-Wikkúaj («Libro de la Disputa») hebreo, que compuso Najmánides a su regreso a Gerona y que, tras ser traducido, sirvió para informar de lo sucedido en Barcelona al obispo de su ciudad.

\footnotetext{
${ }^{46}$ Para la cronología de la disputa, véase A. Tostado, ob. cit., pp. 68-69.

${ }^{47}$ El mesías judío es un rey de los últimos días, restaurador de la gloria del antiguo Israel. Como en la posterior Controversia de Tortosa expresó claramente R. Yuçe Alvo (Yosef Albo) de Daroca, los judíos «esperavan que el Massías vernía a darles solamente prosperidat de los cuerpos e non de salvarles las ánimas, mas que les daría muchos bienes tenporales e los congregaría en su tierra e rehedificaría a Jherusalem e el Tenplo de Salamón materialmente» (Actas castellanas de la controversia de Tortosa, cit. infra, fol. 17r, en el contexto de la discusión de Gé 49,10). Para lo relativo a la visión del tema mesiánico por Najmánides, véase J. Sarachek, The Doctrine of the Messiah in Medieval Jewish Literature, New York, Hermon Press, 1968, pp. 162-191.
} 
Ya en las sesiones del primer día, Fray Pablo y Najmánides chocaron a cuenta de la primera parte del cuento del buey:

Dijo de nuevo fray Pablo que está en el Talmud que el Mesías ya había venido. Y adujo una prueba sacada del libro Lamentaciones Rabbá $(1,57)$ de cierta hagadá: Estaba sembrando un hombre y empezó a mugir el buey. Pasó entonces cierto árabe y le dijo: «iHijo de judío, hijo de Judío! Desata tu buey, desata tu arado, desata tu reja ${ }^{48}$, pues voy a devastar vuestro Templo» ${ }^{49}$. Desató el buey, desató el arado, desató la reja. Volvió a decirle: «¡Ata tu buey, ata tu arado, ata tu reja, porque ha nacido vuestro Mesías!».

Contesté y dije: «No creo totalmente en esa hagadá, aunque es un argumento para mis palabras».

Gritó entonces ese apóstata, diciendo: «iMirad cómo reniega de sus palabras!» Contesté: «No creo realmente que el Mesías naciese en los días de la Destrucción. Por tanto, esta hagadá o no es verdadera o tiene otra explicación en los misterios de los Sabios. No obstante, la admitiré en el sentido que dije "es un argumento para mis palabras", cuando dices que el Mesías nació el día de la Destrucción. Si es así, Jesús no es el Mesías según veis, porque Jesús nació y fue crucificado doscientos años antes de la Destrucción según la verdad, y setenta y tres años según vuestro cálculo».

Y entonces se calló el malvado ${ }^{50}$.

En la doble contestación a su oponente, Najmánides deja traslucir su conciencia del riesgo que supone para el judaísmo la admisión literal de las hagadot como fuente de prueba en la polémica doctrinal. De hecho, esa conciencia motiva el tono tajante de su primera respuesta, que resulta sorprendente en un defensor del judaísmo tradicionalista como él, que necesariamente había de considerar verdadera la lectura literal de las hagadot. Lo contradictorio de su postura - pura táctica defensiva-, que capta de inmediato su oponente, le lleva en seguida a añadir lo que parece la posibilidad de una lectura «misteriosa» de probable tenor cabalístico. Y, sin embargo, vuelve acto seguido a complicarse la vida (y a complicársela a todos los polemistas judíos posteriores a él): con una excesiva confianza en la razón que le otorga el cruce de los datos cronológicos, que descartarían como Mesías tanto al Jesús citado en el Talmud como al de los Evangelios, admite la hagadá del buey en su literalidad.

\footnotetext{
${ }^{48}$ Las fuentes hebreas solo mencionan dos cosas: el buey y el yugo; las cristianas y el Wikúaj de Najmánides, tres: el buey, el arado y la reja/cántaro; el término hebreo que recoje Najmánides es qanqan: «cántaro», pero también «reja de arado».

${ }^{49}$ Najmánides altera el texto rabínico cambiando el tiempo verbal e incluyendo el pronombre posesivo.

${ }^{50}$ A. Tostado, ob. cit., pp. 170-171, con leves correcciones. Texto original hebreo en p. 129.
} 
Al hacerlo, la parte cristiana abre un frente nuevo en la discusión:

Replicó entonces Maestre Guillem, el juez que tenía el rey: «La disputa no es sobre Jesús, la cuestión es si vino o no el Mesías; tú dices que no ha venido, pero vuestro libro afirma que ya ha venido».

Le dije: «[...] los sabios no afirmaron que había venido, sino que había nacido [en tiempo de la destrucción]; [el Mesías] no vino y liberó [a Israel] el mismo día en que nació nuestro padre Moisés, la paz sea sobre él, sino cuando [Moisés] se presentó al Faraón por orden del Santo, bendito sea [...]; entonces vino [...] Así también [...] cuando Elías unja al Mesías por mandato de Dios, entonces llegará el Mesías (p. 171).

La discusión mesiánica se complica así con un nuevo tema: el del Mesías oculto largo tiempo hasta el día de su manifestación como tal. Es, precisamente, el motivo que se lee al trasluz del texto de la segunda parte del cuento del buey, omitida por Fray Pablo, quizá de modo intencionado, para no complicar en exceso sus argumentos. Ahora, sin embargo, este empleará casi todo el resto de la jornada en lo que parece, más que una torpeza dialéctica, un acto de pura y simple provocación, aduciendo como testimonio el que quizá sea el texto más conocido de los que en el Talmud afirman la preexistencia anónima del Mesías:

Volvió a decir ese [Fray Pablo] que se explica en el Talmud que Rabí Yehosúa ben Leví preguntó a Elías: «¿Cuándo vendrá el Mesías?» Y le respondió: «Pregúntaselo a él» Preguntó: «Y dónde está?». Le contestó: «En la puerta de Roma, entre los enfermos» Marchó allí y le encontró; le preguntó y etcétera ${ }^{51}$. Así pues, él ya ha venido y está en Roma (p. 172).

${ }^{51}$ TB Sanhedrín 98a: Cuando Rabí Yehosúa ben Leví encontró al profeta Elías sentado a la entrada de la cueva en la que estaba enterrado Rabí Simeón bar Yojay le preguntó: «¿Lograré el mundo futuro?»; aquel le respondió: «Si este Señor lo desea...». Dijo Rabí Yehosúa ben Leví: «Vi a dos [i.e. a Elías y a mí mismo] pero oí la voz de un tercero». Entonces le preguntó: «¿Cuándo vendrá el Mesías?». «Pregúntaselo a Él»-me respondió. «¿Dónde está?»-pregunté. «En la puerta de Roma». «¿Cómo lo reconoceré?»-insistió. «Está sentado con los pobres leprosos y enfermos; les cura las heridas de una en una, vendándolas y pensando: "Si me necesitan, que no me retrase"». Rabí Yehosúa fue entonces a verle y le dijo: «La paz sea contigo, mi maestro y Señor». «La paz sea contigo, hijo de Leví»-respondió el Mesías. «¿Cuándo vendrás, maestro?»-preguntó el rabino. «Hoy»-respondió el Mesías. Volvió Rabí Yehosúa a donde estaba Elías, quien le preguntó: «¿Qué te ha dicho?». «La paz sea contigo, hijo de Leví»-respondió. «Pues con eso - dijo Elías- te ha prometido el mundo futuro para ti y para tu padre». «¿Cómo puede ser -dijo Rabí Yehosúa- si me ha mentido, diciéndome que vendría hoy, y no ha venido?». «Lo que te dijo -replicó Elías- es: Hoy, si oís su voz (Sal 95,7)».

Sobre el uso de este relato por los polemistas conversos peninsulares (Alfonso de Valladolid, Jerónimo de Santa Fe, etc.) véase A. Alba y C. Sainz de la Maza, «La tradición judía como arma antijudía: los relatos rabínicos de Jerónimo de Santa Fe», en Violence et identité religieuse dans l'Espagne du XV au XVII siècles, coord. de R. Amran, París, Indigo, 2011, p. 280; «Cuentos rabínicos en castellano en el 
La intervención del rey, extrañado por la desmesurada longevidad del Mesías que implica admitir la validez de las dos hagadot discutidas en la sesión, lleva al cierre humorístico de esta, en el que Najmánides responde con socarronería un si es no es irreverente a su monarca:

Replicó entonces nuestro señor el Rey: «Si nació el día de la destrucción del Templo, que acaeció hace más de mil años y aún no ha venido, ¿cómo va a venir?, porque no es propio de la naturaleza humana vivir mil años». Le respondí: «[...] Ya entre nuestros antepasados, Adán y Matusalén vivieron cerca de mil años, y Elías y Henoc, más de mil, pues siguen vivos junto a Dios». Preguntó [el Rey]: «¿Y dónde está ahora [el Mesías]?». Le dije: «Esto no es propio de la disputa y no os voy a contestar. Pero puede que lo encontréis en las puertas de Toledo, si enviáis allí a uno de vuestros legados». Y dije esto en broma (ibid.).

Al día siguiente Najmánides aprovechó el permiso explícito del rey para abrir la sesión insistiendo en el paralelismo entre la longevidad de los patriarcas y la del Mesías oculto en el Jardín del Edén, y en la presencia circunstancial de este en Roma, donde lo encontró Rabí Yehosúa. Y además, y es lo fundamental para acabar de establecer el futuro estatuto de las hagadot en la poética de la controversia doctrinal, Najmánides desplegó al detalle la explicación de su anterior rechazo del cuento del buey y, por extensión, del conjunto de las narraciones rabínicas:

Me levanté y dije: Escuchad, pueblos todos (Miq 1,2). Fray Pablo me preguntó si había venido ya el Mesías del que hablaron los profetas, y dije que no había venido. Y adujo un libro de Hagadás2 en el que se dice que el Mesías nació el mismo día en que fue destruido el Templo. Respondí que yo no creo en eso, aunque es un argumento para mis palabras. Y ahora voy a explicaros por qué dije que no creía en eso. Nosotros tenemos tres clases de libros: uno es la Biblia; en este creemos todos nosotros con una fe total. El segundo se llama Talmud, y es una explicación a los preceptos de la Torá, porque en la Torá hay 613 preceptos y no hay ni uno que no se explique en el Talmud, y nosotros creemos en él, en la explicación de los preceptos. Además tenemos un tercer libro, el llamado Midrás, que quiere decir «sermones», como cuando se levanta un obispo ${ }^{53}$ y pronuncia un sermón y a uno de los presentes le gusta y lo pone por escrito. Y quien crea en este libro, hace bien, y quien no crea, no hace daño. $Y$ tenemos sabios que escribieron que el Mesías no nacería hasta

\footnotetext{
Mostrador de Justicia de Alfonso de Valladolid», en Revista de Filología Española, 93 (2013), p. 21.

${ }^{52}$ Se trata del Midrás Lamentaciones Rabbá.

${ }^{53}$ Najmánides utiliza aquí el término rabínico hegemon, adoptado del griego, que se utilizaba para referirse a una autoridad militar; en el hebreo medieval y moderno puede también designar a una autoridad religiosa extranjera.
} 
cerca del final de los tiempos, en que vendría a sacarnos del exilio. Por eso yo no creo en ese libro cuando dice que nació el día de la Destrucción. Además, le llamamos Libro de Hagadá, que quiere decir «Razionamiento» (sic), es decir, que no es sino cosas que un hombre cuenta a su compañero (p. 173).

La Controversia de Barcelona consagró, sin embargo, para siempre, el uso de haggadot como pruebas cristológicas en el género polémico. Y el cuento del buey seguirá siendo, tanto oralmente como por escrito, una pieza de convicción importante en la discusión de la cronología mesiánica. Sus versiones en lengua romance tendrán, como veremos, vida oral y escrita hasta bien entrado el siglo XV.

\subsubsection{Pugio Fidei}

El Pugio Fidei (El Puñal de la Fe), que fue compuesto por el dominico y hebraísta Raimundo Martí hacia 1280 como consecuencia del relativo fracaso cristiano de Barcelona y con el ojo puesto en la formación de polemistas duchos en el conocimiento y aplicación de la materia rabínica a la confrontación con los judíos, iba a gozar de enorme influencia posterior; en Aragón, por ejemplo, su peso como fuente en la controversia de Tortosa será incontestable. ${ }^{54}$ Estaba, como obra técnica concebida para especialistas clericales, redactada en latín $\mathrm{y}$, que sepamos, no se tradujo nunca a las lenguas romances peninsulares. No añade, pues, nada a la historia de las versiones vulgares del cuento del buey que, como el resto de sus fuentes, cita en hebreo antes de traducirlo al latín. Pero sí que interesa recordar de qué manera, distinta de la ya vista en Barcelona, se utiliza como testimonio en la argumentación antijudía. Porque, al contrario de lo intentado por Pablo Cristiano en 1263, el breve capítulo del Pugio titulado: "Quod Messias judaeorum secundum ipsos natus est illa die qua Templum destructum est a Tito et Vespasiano» ${ }^{55}$ acoge el cuento del buey, y luego su ya citada reelaboración del Bereshit Rabbá Rabbati, así como la anécdota de Sanhedrín 98a que recoge la conversación entre Rabí Yehosúa ben Leví y el Mesías y su interpretación por boca de Elías, como ejemplos de «insania» (p. 348), como «fabulae» (ibid.) cuya credibilidad puede descartarse sin apenas otro apoyo que una ligera glosa de corte histórico-cronológico, reforzada por un par de observaciones lingüísticas de David Qimji, uno de los exégetas y gramáticos judíos contemporáneos de mayor prestigio.

\footnotetext{
${ }^{54}$ No en Castilla hasta el siglo xv, quizá como consecuencia del distanciamiento del latín de los polemistas castellanos anteriores a la crisis de 1391, mayoritariamente conversos, como Alfonso de Valladolid.

${ }^{55}$ Pugio, II c. VI; ed. cit., p. 348.
} 
Del cuento, como de las demás hagadot de asunto mesiánico que recoge el capítulo, puede concluirse lo que Raimundo Martí concluye de su lectura del texto de Sanhedrin: «Nota quod [praedicta traditio]optima est contra Judaeos, quamvis vera non sit nisi sequndum eos» (p. 351) $)^{56}$. El tono general, aun siendo despectivo, no alcanza, sin embargo, la violencia palpable en las actas de las controversias públicas, pero el resultado final es idéntico: sólo la lectura cristiana (y cristológica) de las fuentes judías es correcta.

La inviabilidad del cuento del buey como testimonio mesiánico queda sellada por su asociación con la lectura figurada de Sal 119,85: «Foderunt mihi protervi fossas -vel narraverunt mihi impudentes fabulas-quae non sunt ut lex tua» (p. 349) ${ }^{57}$. Sin embargo, su empleo en el Pugio merece un comentario por su interés para el estudio de la poética del género de la discusión doctrinal. Raimundo Martí incluye solo la primera mitad del relato:

Haec autem insania inde prolabitur, ubi in libro Beracoth Hierosolymitano hoc modo legitur in distinctione quae incipit Hajab Kore [...]: Illa die qua natus est Messias destructa est Domus Sanctuarii, ut ait R. Joden in nomine $R$. Ibbo. Factum est enim quodam Judaeo commovente -id est arantemugivit bos eius coram eo. Transivit autem quidam corvinus ${ }^{58}$, et audivit vocem quae dicit: «Judaee, fili Judaei, solve boves tuos, quia ecce Domus Sanctuarii destructa est»; mugivit bos tempore secundo, et ait [ille còrvinus]: «Judaee, fili Judaei, junge boves tuos, quia ecce natus est rex Messias». Dixit ei: «Quod est nomen eius?». Dixit ei: «Menachem, Consolator». Dixit ei: «Quod est nomen patris eius?». Dixit ei: «Hiskia, Virtus Domini». «Et unde est?» dixit ei. «De domo regia, de Bethlehem Judae», etc.

Dixit R. Abbun: «cur habemus nos discere a corvino isto? nonne Scriptura plena est? Scriptum est enim, Esa. 10 v. 34, Et Libanus cadet in robusto etc. Quid est scriptum consequenter post hoc, Esa. 11 v. 1, Egredietur virga de stipite Isai, et planta de radicibus ejus germinabit vel fructificabit».

Hucusque verba Talmud. (pp. 348-349) ${ }^{59}$.

${ }^{56} \mathrm{El}$ capitulillo se organiza en cinco apartados: I. Messias natus die illa que Templum est destructum $[\mathrm{TJ}+\mathrm{LamR}$ a Lam 1,16 + BRR]; II. Refutatio fabulae recitatae paragrapho primo $[+\mathrm{Sal} 119,85, \mathrm{Ge}$ 49,10]; III. Quod significet«terem» [Is 66,7, Qimhi: Sefer ha-Shorashim, Targum y Sal 57,7]; IV. Ubi tamdiu maneat Messias [BRR, Sanh 98a+Rashi y Sal 95,7]; V. Messias custos sigillorum Dei et Elias secretarius [Mid. Rut 2,14]; VI. Conclusio refutationis.

${ }^{57}$ También la conclusión del cuento por parte de R. Abún es objeto de desprecio: «[...] dicendum, quod licet $R$. Abbun fabulam hanc erubuerit, et ideo per Esaiam hunc errore persuadere voluerit [...]» (p. 349).

${ }^{58} \mathrm{~A} 1$ margen aclara la palabra «corvinus» como «Arabs». En realidad, parece que la extraña presencia de este animal en la versión latina se debe a un error de lectura o copia del original hebreo ('arab, «árabe»), por ברוע ('oreb «cuervo»).

${ }^{59}$ Omitimos el texto hebreo que el autor incluye antes de la traducción latina, así como el correspondiente a los nombres del Mesías intercalados en esta, que Martí transcribe, además, en caracteres latinos. 
La supresión de la secuencia relativa al encuentro del judío con la madre del recién nacido mediante el socorrido expediente del et caetera, no parece deberse a la conciencia de estar citando un texto universalmente conocido, como solía hacerse en el caso de ciertos versículos bíblicos. Mucho más popular que la hagadá del buey sería la de Rabí Yehosúa y el Mesías en la puerta de Roma, que Raimundo Martí cita sin cortes y enriquecida por las matizaciones de Rashi; sin embargo, la amputación del pasaje del Talmud de Jerusalén se hace, a nuestro entender, con una finalidad práctica. Esta no es otra que, una vez refutada la cuestión de la fecha tardía del nacimiento del Mesías, abordar la de su presunta y milenaria vida oculta previa a su manifestación como redentor de Israel, pero no a partir del relato en tono menor, casi idílico, de nuestra hagadá, sino del más dramático, casi truculento, incluido en el Bereshit Rabbá Rabbati medieval, al que el protagonismo de Elías, además, le añade un plus de incongruencia cronológica muy aprovechable desde la postura argumentativa del autor. Esta se ve reforzada, además, por la cita, acto seguido, del relato de Sanhedrín 98a, cuyas claves explica, precisamente, el propio Elías.

La mención parcial de nuestro texto parece, pues, deliberada, y puede considerarse como una consecuencia más de la aplicación de la regla de fragmentación textual que, junto con la de descontextualización, conforma el eje central del discurso polémico-apologético doctrinal desde sus orígenes más remotos ${ }^{60}$.

\subsubsection{Jerónimo de Santa Fe: El Sefer ha-Piqqurim (1412) y la Controversia de Tortosa (1413-14)}

La Controversia de Tortosa, que se desarrolló entre el 7 de febrero de 1413 y el 13 de noviembre del año siguiente constituyó la gran fiesta de la doctrina cristina triunfante sobre un adversario judío en regresión tras los veinte años de crisis iniciados con las persecuciones de 1391. El contexto no favoreció que se reprodujera el clima de verdadero torneo doctrinal que siglo y medio

\footnotetext{
${ }^{60}$ Confirman nuestras apreciaciones el que, en las conclusiones finales del capítulo, Martí se refiera únicamente a la primera parte de la Haggadá del buey: «Ecce qualia fabulantur Judaei de suo ficto Messia. Si ista namque vera fuissent, nequaquam post destructionem Templi fecissent sapientes ipsorun Ben Kosbam Messiam [...] Nec hoc dicendo inficior diabolum loqui potuisse per corvinum ante dictum, id est per aliquam corvini generis avem; vel per aliquam arabis alicuius effigiem; et transformare se in Eliam, ut Judaeos tali supplantaret errore qui transfigurare quandoque legitur in angelum lucis. Porro quia jam supra ostensum est inane esse, hac frivolum, quicquid Judaei dicunt probando Messiam esse natum in die destructionis Templi, consequens est cuncta ista esse fabulosa quae circa suum fictum Messiam agi, et acta fuisse delirant» (p. 352).
} 
antes había presidido la controversia barcelonesa de 1263, y la más que digna defensa judía quedó ahogada en el mar de «información» cristiana con que, auctoritates judaicas en mano, el converso Jerónimo de Santa Fe (antes Rabí Yehosúa ha-Lorquí), médico del papa Benedicto XIII, y sus colaboradores abrumaron a los más prestigiosos rabinos aragoneses del momento ${ }^{61}$.

El Papa, que precisaba reforzar su imagen pública en un momento en el que su poder al frente de la Iglesia de Aviñón se encaminaba hacia su ocaso, transformó lo que en principio era un proyecto más modesto de disputa entre Jerónimo, «in litteris hebraicis et arabicis eruditus», y sus ex-correligionarios y paisanos de Alcañiz en una campaña de catequesis forzosa a gran escala, dirigida a los representantes de todas las aljamas de Aragón. La impotencia judía para hacer prosperar ninguna estrategia de defensa tuvo consecuencias graves para su comunidad, ya que puede relacionársela con el espectacular aumento de conversiones detectable en esos meses, que desangró, aún más, a las ya muy debilitadas juderías de la corona aragonesa ${ }^{62}$.

El doble enfoque tradicionalmente aplicado por parte cristiana a las hagadot rabínicas sigue vigente, como era de esperar, en la planificación de la Controversia. Se detecta ya en algunos opúsculos de carácter preparatorio para la discusión -hoy conservados en una versión castellana redactada muy poco después de la clausura del acto- ${ }^{63}$, y orienta las dos fases en que se

\footnotetext{
${ }^{61}$ Se hizo notar la participación en las sesiones turtusíes de Fray Vicente Ferrer, alma de la predicación catequética a los judíos en esos años, y del erudito y poderoso converso burgalés Pablo de Santa María, responsable de las leyes castellanas de segregación de 1412; véase, Jerónimo de Santa Fe, Obras completas I. Errores y Falsedades del Talmud, ed. de C. del Valle, Madrid, Aben Ezra, 2006. Para Tortosa son esenciales Y. Baer, Historia de los judios en la España cristiana, Barcelona, Riopiedras, 1998, pp. 611-684; A. Pacios, La Disputa de Tortosa, Madrid-Barcelona, CSIC, 1957, 2 vols. (transcripción de las actas latinas en vol. II) y las actas castellanas conservadas en el Ms. 2365 de la Biblioteca Universitaria de Salamanca.

${ }^{62}$ Las actas de la Controversia hacen referencia a ese acelerado goteo de conversiones, destacándolo incluso con un epígrafe propio: «Cómo se convertieron ciertos judios a la fe: Durante aqueste tienpo sobre dicho todas semanas venían al conoscimiento de la verdat e confesavan aquella diversos judíos; e [...] muchos otros que se convertían por otros logares del regno, así en Çaragoça como en Calatayud como en Alcanis e por otras aljamas del regno, sobrepujantes en el dicho a[ño] más de CCL ánimas; cuando oían en sus logares las razones que se davan tan firmes e tan notables por el dicho maestre Jerónimo e las respuestas tan flacas que los rabís fazían, venían a confesar que la fe cathólica era la verdadera e bateavanse con gran devoción» (Ses. XXII, 17 de abril de 1413, fol. 50r; lat., A. Pacios II, p. 151).

${ }^{63} \mathrm{BNE}$, Mss 10276. Se trata del escrito Razones contra los judios negantes el Advenimiento del verdadero Mesías (fols. 1-40), donde los textos rabínicos se aplican a probar que Jesús cumple las condiciones mesiánicas exigidas por el Judaísmo, y del Tractado [contra] las vanidades e abhominaciones falladas en el Talmud (fols. 40-63v; es el que C. del Valle edita como Errores y falsedades del Talmud, cit.). Jerónimo hizo circular en 1412 por las aljamas aragonesas la versión hebrea de Razones, que fue bautizada por sus destinatarios con el nombre de Sefer ha-Piqqurim (Libro de las herejías) y utilizada luego - por ejemplo, en la sesión LVIII- en Tortosa. Sobre sus haggadot, véase A. Alba y Sainz de la Maza, «La tradición judía como arma antijudía».
} 
dividieron las sesenta y nueve sesiones celebradas en Tortosa y, desde el otoño de 1414, en San Mateo. Casi todas ellas se consagraron a la demostración de que la figura histórica de Jesús cumplía las veinticuatro condiciones que, según el judaísmo, ha de poseer el Mesías. La argumentación desarrollada durante las discusiones se apoyó, de modo acumulativo, sobre las hagadot rabínicas, en estrecha conexión con determinados pasajes bíblicos y con algunos comentarios exegéticos de Abraham ibn Ezra, Rashi o Maimónides. Como es usual en el género polémico, fueron exactamente las mismas fuentes las que proporcionaron los textos en los que se centraron las últimas sesiones de la Controversia - a partir de la LVIII (2 de marzo de 1414)consagradas a rechazar la condición de Ley Oral del Talmud mediante el desenmascaramiento de sus supuestos errores y pasajes escandalosos.

En el vano empeño de Jerónimo de convencer de la verdad mesiánica cristiana a su antiguo conocido de Alcañiz, Rabí Astruch, y al resto de sus compañeros, el cuento del buey aparece, tanto transcrito como mencionado en glosas o simples citas, de modo reiterado durante los casi dos años que duraron los debates. A esta abundancia contribuye el hecho de que, si bien la Controversia se desarrolló al principio según el formato de disputa oral corriente en actos de este tipo, el Papa, irritado ante la falta de resultados positivos, ordenó, al final de la sesión IX (20 de febrero de 1413) retomar la discusión desde su comienzo, pero articulando ahora cada intervención sobre la base de memorandos redactados con antelación ${ }^{64}$.

En los argumentos desplegados en cualquiera de los dos formatos, nuestro cuento se aplica como prueba literal de -en palabras del tratadito preparatorio ya citado- «que el tiempo asignado del advenimiento del Massías era en la fin del segundo Templo de Jerusalén, poco tiempo antes de la destruición del dicho Templo» ${ }^{65}$.

Jerónimo se aparta, pues, de la línea crítica negativa representada por el Pugio Fidei para retomar, aunque con argumentos más prolijos y una mayor y

\footnotetext{
${ }^{64}$ Por lo que se refiere a la lengua de la controversia, coincidimos con Del Valle en que «el latín fue la lengua protocolaria, para momentos solemnes, como la inauguración de los debates, mientras que el grueso de las disputas se hacía en el antiguo español [sic], lengua vehicular en todo el reino de Aragón, y, en casos contados, también se debió [de] utilizar el hebreo» (Jerónimo de Santa Fe, Errores, p. 44); ese «antiguo español», o su dialecto aragonés, pudo ser también, para alguno de los participantes, la lengua catalana.

${ }^{65}$ Razones, fol 7v. Por supuesto que los datos que sobre el Mesías desgrana la primera secuencia del cuento -única que, como se verá, parece haberle interesado a Jerónimo aquí y en Tortosa- confirman la mesianidad de Jesús como hijo de Dios Padre y redentor del pecado original. El desfase cronológico que plantea la lectura literal del relato lo salva, auctoritates rabínicas mediante, dejando, finalmente, probado y establecido que la verdadera destrucción del Templo se produce en el momento de la Pasión, en el cual «perdió la Arca toda su sanctidad y cessaron todos los miraglos que se fazían en ella» (fol. 12r); así, en el año 70, los romanos se habrían limitado a destruir un lugar vacío de toda significación espiritual.
} 
más impune agresividad, los planteamientos de la controversia de Barcelona. Sin embargo, conoce a fondo la obra de Raimundo Martí, cuyas referencias al Bereshit Rabbá Rabbati aprovecha, por ejemplo, ampliamente ${ }^{66}$; y va a ser el Pugio, y no las fuentes rabínicas, que tenía fácilmente a su alcance, su referencia fundamental a la hora de citar por extenso el cuento del buey.

La hagadá en cuestión se transcribe en las actas de las sesiones IV (10 de febrero de 1413), XV (22 de marzo) ${ }^{67}$, XXVII (26 de mayo) y XLVII (22 de diciembre), y se comenta o menciona, por ejemplo, en las sesiones VIII (17 de febrero de 1413), XVII (3 de abril), LVI (23 de febrero de 1414), LVII (post. 23 de febrero ${ }^{68}$ o LVIII ( 2 de marzo).

Las versiones castellanas del relato que hemos conservado (la incluida en Razones y las de las actas en romance transcritas en el manuscrito de Salamanca ${ }^{69}$ ), aunque respetuosas con la exigencia de literalidad que presupone su uso como testimonio, difieren todas entre sí en detalles, a veces, muy significativos. Concuerdan, sin embargo, en dos rasgos fundamentales para su funcionamiento en el contexto del debate mesiánico. Uno es que se citan siempre incompletas, reducidas, como en el Pugio Fidei, a la secuencia narrativa del encuentro del árabe con el narrador judío. El otro es que Jerónimo prescinde de la versión literariamente más elaborada, la contenida en Lamentaciones Rabbá; coincide en ello, igualmente, con Raimundo Martí ${ }^{70}$, pero, a la vez, el prescindir del texto midrásico refuerza su autoridad para reclamar de sus oponentes la aceptación literal de un testimonio que para ellos posee todo el peso de la Ley Oral ${ }^{71}$.

${ }^{66}$ Véase las Actas latinas editadas por A. Pacios, passim, así como las citas incluidas en el ms. de la BNE.

${ }^{67} \mathrm{El} \mathrm{ms}$. castellano salta desde mediados de la ses. XII (entre el 1 y el 15 de marzo) a la ses. XVII ( 3 de abril), pero en la XV se incluye el cuento del buey, de nuevo aducido como prueba por Jerónimo (A. Pacios, ob. cit., II, p. 105).

${ }^{68}$ La sesión LVII no se fecha en las actas latinas (ibid., p. 483); su romanceamiento se incluye, omitiendo el texto de la sesión LVI, a continuación de la fecha de esta (fol. 254v).

${ }^{69}$ Las actas castellanas ocupan los 343 primeros folios del Ms. 2365 de la Biblioteca Universitaria de Salamanca, un infolio de 250 x $170 \mathrm{~mm}$., en papel y letra gótica cursiva del s. xv; para su descripción completa, véase O. Lilao y C. Castrillo, Catálogo de manuscritos de la Biblioteca Universitaria de Salamanca, II. Manuscritos 1680-2777, Salamanca, Universidad, 2002, pp. 751-752.

${ }^{70}$ Coincidencias reforzadas, en el caso de la versión utilizada en la ses. XVII -dedicada a confirmar el nacimiento del Mesías en Belén-, por el hecho de aducir a continuación como prueba el mismo relato de Bereshit Rabbá Rabbati ya comentado, al hablar del Pugio: «Una vez iva Helías por camino en el día que fue la destrucción del Tenplo e oyó una fija de vos ['voz del cielo'; calca hebr. bat qol,] etc.» (fol. $81 \mathrm{v})$.

${ }^{71}$ Como dice a propósito de otro pasaje, «la actoridat en sí verdadera es, pues conplida es en el testo del Talmud, el qual vos otros sodes tenudos de creer como aquel que dezides que es Ley de Boca» (197v). Sobre ello, véase M. Orfali, Talmud y Cristianismo. Historia y causas de un conflicto, Barcelona, Riopiedras, 1998, pp. 11-12. Ni que decir tiene que, cuando le conviene, Jerónimo niega la interpretación literal que los judíos dan a determinadas haggadot; lo hizo, por ejemplo, en esa misma sesión con la 
Los rabinos presentes en Tortosa fueron conscientes tanto de la mutilación del relato talmúdico como del olvido de la versión contenida en Lamentaciones Rabbá desde el mismo momento en que, en la IV sesión de la controversia (10 de febrero de 1413), Jerónimo citó por primera vez el texto de Berajot ${ }^{72}$ :

A la dicta actoridat respuso Rabí Astruque e dixo que él tenía en su libro la dita actoridat e sacó en su mano una foja de papel vieja et leyó allí que aquel judío que labrava que se fizo vendedor de calçuelas de criaturas por saber cuál era la madre del Massías et caetera. Enpero dixo que aquesta istoria era recitada en la glosa de la Lamentación de Jeremías e ansí que fablava en la primera destrución del Tenplo non de la segunda. E aprés maestre Jerónimo le provó cómo la dita istoria fablava de la destrución segunda y por muchas rasones e pruevas nescesarias. E el dicho rabí, convencido de aquesto, dixo que verdat era que era nascido ${ }^{73}$.

Casi inmediatamente se hará presente, por boca de Rabi Todros, la clásica estrategia defensiva judía:

Aquella istoria de cómo el árabo fablava al labrador non se devía alegar por cosa auténtica, ca eran fablillas, et caetera; e que lo bueno devía seer preso bueno e lo malo de poca firmeza dexarlo estar. E aquello mesmo replicó rabí Astruque, e dixo más: que la Biblia e las glossas de los dotores aprovadas por Rabina e Rabansse eran cosas muy auténticas, mas los sermones non eran dichos que non se pudiesse negar (fol. 11r).

De nuevo, y como cada vez que los judíos intentaron apartarse en esos meses mínimamente de la literalidad del cuento, la autoridad de la «Ley de Boca» se les impondrá como una barrera infranqueable:

Sobre aquello provó maestre Jerónimo cómo la dicha estoria era escripta en el testo mesmo del Talmud, en aquello que es autenticado por los dichos Rabina e Rabase, lo cual todo judío es tenudo de creer $^{74}$.

\footnotetext{
historia de Rabí Yehosúa ben Leví y el Mesías (fol. 197rv).

${ }^{72}$ Véase el texto infra en nuestra edición en paralelo de los distintos testimonios.

${ }^{73}$ Fol. 10rv. Nótese que el argumento cronológico empleado por Rabí Astruch es inexacto: Lam.R. es precisamente una búsqueda de explicaciones a la situación creada por la caída del segundo Templo.

${ }^{74}$ Fol. 11r. $C f$. también, como ejemplo de alusión sin cita a nuestro cuento: «Responde el judío que de bramidos de bueyes nin de agüeros non se deve fazer mención nin dar fe alguna et cetera. Contra aquello digo que si yo desfundasse mi entención por alguna señal de agüeros que nosotros oviéremos visto, la ora ellos dirían razón de non dar ý fe; mas yo non digo, sinon sus mesmos rabís en el testo del Talmud dan plenaria fe a aquello e fundan e pruevan por allí seer el Massías nascido en el mismo tienpo que fue la destrución del Tenplo [...] non á judío que con buena razón lo pueda contradezir, mayormente que viene luego aquel dotor rabí Havon y lo confirma con palabras de Ysaý» (Ses. XVII, fol. 33v).
} 


\section{A. Alba Cecilia y C. Sainz de la Maza}

Presentamos a continuación los diferentes textos del cuento del buey utilizados por Jerónimo de Santa Fe en su intento de demostrar las tesis cristianas relativas al lugar y momento del nacimiento del Mesías. Para facilitar la comparación de las diferentes versiones, hemos adoptado una disposición paralela de los distintos segmentos textuales en los que se puede dividir el relato hagádico. El texto latino que corresponde al aducido por Jerónimo en el curso de la sesión XV no tiene correspondencia en el manuscrito castellano, ya que se incluye en las partes omitidas por este; sigue, sin embargo, muy de cerca la versión incluida en la sesión XXVII, excepto para el comentario final, que esta omite.

En esta disposición paralela, va en primer lugar la versión más completa del texto (Sesión XLVII, S47), seguida, por el orden de su aparición durante la disputa, de las contenidas en las sesiones IV (S4) y XXVII (S27); en último lugar, la contenida en Razones (R) que, aunque anterior, en principio, a las demás, conservamos en una redacción posterior a la clausura de la Controversia.

\section{Mención de LA Fuente utilizada:}

S47 Item por más confirmar la dicha conclusión les fue alegada otra actoridad, la qual es en el Talmud Gerusalmista en el libro de Berahot, c $^{\circ}$. "Hayacore", e es tan bien en el libro llamado Equa rrabaçi i.e. Lamentación Magna, el tenor de la qual es:

S4 Por más provar que el Massías era venido, el dicho maestre Jerónimo alegó una actoridat del Talmud que es en el libro de Berahot Jerusalmista c. "Hayacoré", la cual dize ansí:

S27 Quarta prueva: es por el testo del Talmud [así] por una actoridat que se falla en el libro de Berahot del Talmud Jerusalmi, c. que comiença "Haya core", la qual dize así:

$\mathrm{R} \quad$ Item para más provar aquesta conclusión, fallamos que dize el Talmud Iherolimicasta en el libro de Berahot en el capítulo "Hayacore", e en Equarabati, i. e. Lamentación Magna, dize así:

Tanto S47 como R, siguiendo el modelo del Pugio, mencionan las dos fuentes hebreas existentes, aunque sólo se utilizan el texto talmúdico. 


\section{AtribuCión DEL RELATO A UNA AUTORIDAD RABÍNICA:}

S47 Dize Rabí Yodán de nonbre de Rabí Iba: En aquel día que fue nascido el Massías, en aquel día fue la destrucción del Tenplo.

S4 om.

S27 Dize Rabí Yodán en él que el día que fue la destrución del Tenplo nasció el Massías.

R om.

S47 reproduce de forma completa la doble atribución rabínica original, pero añade, como parte de la misma, la correlación entre el nacimiento del Mesías y la destrucción del Templo. S27, por su parte, invierte el orden: nombra primero la destrucción del Templo y luego el nacimiento del Mesías. S47 coincide con el Pugio, en el que el orden no parece ser indiferente: el nacimiento de Jesús hace prescindible el Templo y, por consiguiente, la religión judía. La fórmula empleada en S27 resultaría más aceptable para el judaísmo: la consumación del desastre da paso inmediato al germen de la futura liberación.

3. Mugidos Del BueY y CONVERSACIÓN ENTRE EL ÁRABE Y EL JUDÍO:

S47 Acaesció a un judío que estava labrando e bramó el buey. E passó un árabo e oyó la boz e dixo le: «Judío, fijo de judío, suelta tus bueyes e tu parejo, que el santuario se destruye». Bramó otra vez e díxole: «Judío, fijo de judío, ata tu buey e ata tu parexo, que ya es nascido el rey Massías».

S4 Acaesció a un judío que estava labrando e bramó uno de los bueyes. E passó un árabo e díxole: «Judío, fijo de judío, desanpara tus bueyes e tu lavor que [v]uestro ${ }^{75}$ Santuario se destruye». Tornó a bramar el buey. Díxole el árabo: «Jodío, fijo de jodío, enpareja tus bueyes e torna a labrar, que vuestro Massías es nascido».

S27 E acaesció a un judío que estava labrando e bramó su buey. E pasó un árabo e oyó la voz del buey, e dixo: «Judío, fijo de judío, desuelta tus bueys e desenparéjales, que vuestro Santuario se destruye». Tornó el buey a bramar e dixo el árabo: «Judío, fijo de jodío, enpareja tus bueyes, que nascido es el rey Massías».

${ }^{75}$ vuestro: Ms. nuestro. 


\section{A. Alba Cecilia y C. Sainz de la Maza}

$\mathrm{R} \quad$ Acaesció a un judío que estava labrando e bramó el buey. E passó un árabe e oyó la boz del buey, e dixo: «Judío, fijo de judío, suelta, suelta, suelta tus bueys e tu parejo, que vuestro Sanctuario se destrúe». Tornó el bue a bramar. E díxole el árabe: «Judío, fijo de judío, liga tus bueys e enparéjalos, que nascido es el rey Massías».

Todas las versiones coinciden con ligeras variantes, excepto R. Cabe preguntarse si el triple imperativo empleado por Jerónimo posee algún tipo de resonancia trinitaria.

\section{Prolongación de la conversación: Datos sobre el Mesías:}

S47 Díxole el judío: «¿E cómo es su nonbre?». Respondióle: «Menahen, i. e., Consolador». E díxole más: «¿Cómo es su nonbre de su padre?». Respondióle: «Ezechías, i. e., Fortaleza de Dios». Dixole: «¿De dó es?». Respondióle: «De casa real, de Belem $<$ de $>76$ Judá».

S4 Demandó el judío: «¿A dó es?». Dixo el árabo: «En Betlem, de tierra de Judá».

S27 Demandóle el judío: «¿Cómo es su nonbre?». Respúsole: «Menahem, Consolador». Preguntóle el judío: «¿Cómo es el nonbre de su padre?». Respúsole: «Ezechías, i.e., Fortaleza de Dios». Preguntóle más el judío: «¿E a dó es él nascido?». Respúsole: «En Belem de Judá».

$\mathrm{R}$ Díxole el judío: «¿Cómo es su nonbre?». Díxole: «Menahen, i. e., Consolador».

Díxole más el judío: «¿E cómo es nonbre de su padre?». Díxole: «Yzachías, i. e., Fortaleza de Dios». Díxole más el judío: «¿E dó es nascido?». Díxole: «En Betleem de Judá».

Prácticamente la única diferencia está en la identificación del lugar de nacimiento: S47 coincide con Berajot y el Pugio: «De domo regia, de Bethlehem Judae». S4 acentúa radicalmente su tendencia a citar el cuento de forma abreviada.

\footnotetext{
${ }^{76}$ de: Ms. om.
} 
S47 Dice Rabí Abon: «E ¿qué nos cunple aprender esto de los árabos?. Que esto claro es: Et Libanus cum excelsis cadet e Egredietur virga de radice Gesse».

S4 et caetera.

S 27om.

R Dize Rabí Abán: «¿E qué nos cale aprender de los árabes?. Que testo claro es de Ysaýas, que dixo: Et Libanus cum excelsus cadet. E dize luego después: Egredietur virga de radice Jesse».

R es la más completa y fiel al texto talmúdico, y la más cercana al Pugio. S4 confirma su carácter de cita abreviada, y S27 pasa directamente al comentario de Jerónimo: «Catad cómo paresce magnifiesto por el testo del Talmud cómo el Massías era nascido en Betlem» (fol. 81rv).

A lo largo de las distintas sesiones mencionadas, el cuento del buey irá apareciendo asociado a la refutación de los variados intentos judíos de desactivar su valor como testimonio favorable a la mesianidad de Jesús a partir de sus particularidades cronológicas, históricas y gramaticales, y hasta de su posible sentido figurado. De todo ello, el maestre Jerónimo hace un resumen compacto y triunfal en el curso de una de las sesiones de recapitulación -la XLVII- del tramo final de la controversia, la última, como sabemos, en la que se citó completo el cuento del buey.

Cerramos este estudio con la transcripción de dicho resumen, que complementamos con una parte de la sesión LVII, un texto que nos ilustra acerca de la relativa simplicidad conceptual en la que, con respecto a nuestro cuento, se desarrolló la discusión mesiánica, pero que, a la vez, llama la atención por incluir, como confirmación indirecta de las afirmaciones de Jerónimo, varias comparaciones desarrolladas en forma de relato que resultan muy próximas por su planteamiento a los meshalim que abundan en la literatura rabínica. De extraordinario interés, por sus características y por su despectiva brutalidad, es, además, la respuesta que el converso da al intento judío de leer el cuento del buey como «metáfora e figura» (fol. 261r): aprovecha, en efecto, para desplegar su propia y original exégesis figurada del texto con el fin de aplicarlo a la proclamación, no solo del cumplimiento del adviento mesiánico en la persona de Jesús, sino de las maldades acumuladas 
en el Talmud y de la necesidad que tienen de convertirse sus, para él, ciegos, pero con seguridad, en aquel momento, mudos e indignados contrincantes ${ }^{77}$.

\title{
SESIÓN XLVII (viernes ${ }^{78} 22$ de diciembre de 1413; fol. 199v). \\ Tras la transcripción del cuento del buey, Jerónimo hace un resumen de las discusiones habidas en relación con éste:
}

\begin{abstract}
Sobre la dicha actoridat vosotros fiziestes ciertas respuestas, las quales todas vos fueron muy bien revocadas. E a la final en la que más firmastes fue dezir que quando el árabo dizía: «es nascido», quería dezir que era ordenado que nascería. E para cuidar provar aquesto troxiestes semejança de algunos vocablos que son en las profecías posadas ${ }^{79}$ en tienpo presente e se ha a entender por el tienpo advenidero.

E luego yo repliqué diziendo que tal natura de fablar bien se falla a las vegadas en la Biblia e en las profecías, porque son testos obscuros e porque todas las cosas futuras son presentes a Nuestro Señor, mas quanto en las palabras de los dotores que son declaradores de las profecías nunca se falla tal natura de fablar, nin tomen un tienpo por otro. E señaladamente, que en la dicha actoridat ha tantas afrontaciones ${ }^{80}$ a mostrar que el nascimiento suyo era ya presente. Lo primero, que dize en el comienço de la actoridat: «Dize Rabí Odam: "En el mismo día que fue la destruición del Santuario fue el nascimiento del Massías"» [Cf. Ses. IV].
\end{abstract}

Iten, que demandó el judío labrador al árabo cómo ha nonbre, e cómo ha nonbre su padre e de qué linage es, e en qué logar es; que non sufre la razón que todas aquestas palabras querían dezir «ordenación» e non cosa de fecho. Iten, que si lo que dizía el árabo al labrador quería dezir que el Tenplo de

${ }^{77}$ Conservamos un último eco del romanceamiento del cuento del buey utilizado por Jerónimo de Santa Fe en Tortosa. Se incluye en la versión judeo-española del Shebet Yehudá («Vara de Judá») de Selomó ben Verga, compuesto ya en el exilio sefardí de la primera mitad del s. XVI: «Y enpezó Ĝerónimo un maamar que dijo el Midráš Ejá que un buey de un jiidió estaba gimiendo; pasó un 'arabí por allí le dijo: "Ĵidió, ĵidió, desáta tu buey que el Bet hamicdás se estruyó" y el ĵidió lo désató. Ĝimió el buey segunda veź, le dijo el 'arabí: "Jiidió ata el buey, que ya nació el mašíạ̣”. Con que se vee de este maamar claro que el diya que se estruyó el Bethamicdás nació el mašíạ̣» (apud N. Muñoz Molina, Edición filológica de los diálogos renacentistas de la edición judeoespañola aljamiada del Séfer Šébet Yehudá de Belgrado, 1859, Tesis Doctoral, Madrid, UCM, 2013, p. 195). En la versión hebrea de la obra se incluye solo una breve mención del cuento (Véase, Shelomoh ibn Verga, La vara de Yehudah (Sefer Šébet Yehudah), trad. de M. J. Cano, Barcelona, Riopiedras, 1999, p. 181).

${ }^{78}$ viernes: así en Actas lat.; Ms. miércoles. Véase A. Pacios, ob. cit., II, p. 395.

${ }^{79}$ posadas: asentadas, puestas por escrito. Cf. J. Fernández de Heredia, 1376-1396: «aquellas actoridades las quales e podidas hauer he posadas en la present obra» (CORDE, de donde tomaremos todas las citas infra).

${ }^{80}$ afrontaciones: 'lindes', 'elementos fronteros', aquí como 'términos de comparación contiguos en el texto'. $C f$. CORDE, con ejemplos de documentos notariales -muchos, aragoneses- desde 1216. 
fecho se destruía, pero que ya por aquello non cunplía de desenparar su lavor porque ordenado era que nascería / [fol. 200r] Massías de allí en mill e tantos años, veamos, ¿qué consolación era esta al judío?; que menos de aquello ya sabía el judío que en algunt tienpo Massías avía a nascer, que artículo era de su creencia.

Esto non era más sinon como a un omne, por mandamiento del rey, le robasen su casa e le tomassen sus bienes e lo metiessen en prisión para toda su vida, e viniesse alguno por consejarlo e le dixiesse: «Non cures de todo esto; está alegre, que sepas que de aquí a mill e tantos años nascerá otro rey, el qual mandará tornar todo esto âquellos que vernán de tu linage». Veamos aqueste omne si queda pont ${ }^{81}$ consolado; yo digo que non.

Iten, paresce que el dicho nascimiento era presente e real, por la alegación que dize el otro dotor al fin de la actoridat del testo de Ysaý: Et Libano et caetera (E el Tenplo caerá e el Massías verná). E non podedes dezir que estas dos partes de la prophecía, i. e., el caer ${ }^{82}$ del Tenplo e el venir el Massías, que son en diversos tienpos, porque el dicho dotor Rabí Avón non trae a otra entención esta profecía sinon para provar que las dos cosas avían a seer en uno. E si vosotros otro seso dades a la profecía non inpunades a mí, sinon al dotor, el qual avedes por auténtico. E a mí bástame que vuestro dotor dé tal seso a la actoridat que sea consonal con la conclusión mía: que el Massías es venido, porque cerca la opinión e alegación de aqueste dotor fago una conseqüencia atal: quando el Tenplo / [fol. 200v] sería destruido el Massías devía seer nascido; mas el Tenplo es ya destruido, [er]go el Massías es ya nascido [Cf. Ses. XXVII].

Iten, por mayor sinrazón de vosotros, quando razonades por escripto o de palabra en este acto nonbrades esta notable actoridat en nonbre de «fablilla» e dezides: «la fábula del árabo». Guardat, varones, que, fablando con onor, fuerte vós errades, ca yo non me alego ${ }^{83}$ aquí de fablar del árabo nin del llamar del buey, mas alego que dos dotores vuestros dan sentencia definitiva que la destruición del Tenplo e el nascer del Massías fue todo en uno. E el primero, por confirmar su opinión, alega las palabras del árabo, e el otro, las palabras de Ysaý profeta; pues no es fablilla, antes es sentencia de dotores puesta en vuestro Talmud e profecía.

Pero a la final, desque non podedes foir, oviestes a otorgar por fuerça de razón que verdat era que en aquella ora de la destruición era nascido, enpero que non era divulgado nin mostrado. E luego nuestro señor el Papa vos interrogó que, pues nascido era, que dó estava. E vosotros respondiestes que la opinión

\footnotetext{
${ }^{81}$ pont: en absoluto, nada. $C f$. J. Fernández de Heredia: «yo non dubdo pont que por razon [...] del tu advenimiento los carthagineses han rompida la sperança de la paç».

${ }^{82}$ caer: Ms. caguer; Actas lat.: casus seu cadencie.

${ }^{83}$ alego: Ms. alegro.
} 


\section{A. Alba Cecilia y C. Sainz de la Maza}

de algu[n]os era: «en Roma», e opinión de otros: «en Paraíso terrenal»; e que era verdat que era nascido, mas non venido [...] [Cf. Ses. IV].

Iten, otorgaron que otro de los rabís falló en su libro, el qual leyó allí en público, que la dicha actoridat dizía que el dicho judío labrador se avía fecho vendedor de calçuelas de niños e se fue con ellas a Belem por conoscer a la madre del Massías [Cf. Ses. IV].

Al final de la sesión, los rabinos intentaron desdecirse de su aceptación del nacimiento del Mesías, pero acabaron confirmándola «por interrogación fecha a cada uno de los singulares de vosotros mediante jura en el rótulo de la Ley» (i.e., los rollos de la Torá; fol. 201r), lo que da una idea de lo expeditivo de los procedimientos adoptados por los cristianos durante la controversia.

SESIÓN LVII (post. 23 de febrero de 1414; fol. 260r).

Jerónimo responde a los argumentos desarrollados por rabí Astruch en la sesión LVI:

E en el seteno punto dize ansí [el judío]: «porque cierto es que la destrucción del Tenplo se fizo en grant tienpo, e que quando fue destruido, hoc encara ${ }^{84}$, mucho tienpo ante se sabía por todo Israel, e non calía ${ }^{85}$ al árabo nin al bramido del buey que lo notificasse; mas paresce que esto fue ante de la destrucción et caetera».

Digo que todas estas palabras son contra verdat, porque la destrucción del Tenplo en un día se fizo; que bien Titus $<$ lo $>^{86}$ tovo grant tienpo sitiado, enpero todos días salían a pelear los de dentro contra los de fuera e avían grandes escaramuças fasta tanto que se entró / [fol. 260v] la cibdat. E el día mismo que se entró dieron fuego al Tenplo, segunt que todo esto más largamente se paresce por el Josefus ${ }^{87}$. Pues síguesse que la destrucción del Tenplo non fue en grant tienpo como él posa.

Iten, a lo segundo que dize que luego se $[\sup ] \mathrm{o}^{88}$ por todo Israel e non calía el árabo dezirlo, digo que esta razón es falsa, porque, segunt en el Talmud se posa que la tierra de Israel á CCCC leguas de luengo e CCCC de ancho, pues

\footnotetext{
${ }^{84}$ hoc encara: por otra parte; aun más. Cf. J. Fernández de Heredia: «las oraciones [...] millor se ofrescan entendibles a los que las leyeren, hoc encara, que qualquier pueda auer compendioso sumario de la dicha istoria $[\ldots] »$.

${ }^{85}$ calía: era necesario. $C f$. San Vicente Ferrer, 1411-1412: «a los apóstoles [...] non les calía saber la batalla del Antichristo».

${ }^{86} \mathrm{lo}$ : Ms. om.

${ }^{87}$ Véase Flavio Josefo, Las guerras de los judios lib. VI, 4.5-7, en F. Giuseppe, La guerra judaica, II (libri IV-VII), ed. bilingüe G. Vitucci, Milano, Mondadori y Fondazione Lorenzo Valla, 2005, $9^{\mathrm{a}}$ ed., pp. 366-371.

${ }^{88}$ supo: Ms. puso.
} 
logar avía en la tierra que era más lexos de Israel que dos vegadas de aquí a Granada. Pues posemos que el señor rey de Aragón toviesse sit[i]ada Granada grant tienpo; cierto es que el moro menor ${ }^{89}$ que está dentro en Tortosa toda ora estaría a esperança que no la podería conquistar. Pero quando la avrán conquistado, passará algunt día ante que se saprá en Tortosa. E quando âquel moro de Tortosa plegará ${ }^{90}$ la nueva que Granada es presa, non ay dubda que se atristaría e se terná por desanparado. E si, luego en aquel instante, le vinía otra nueva, la qual dixiesse: «Guarda que el Soldán viene con cient fustas grossas para cobrar Granada e es en el estreito ${ }^{91}$ de Gibraltar», e sin dubda que este dicho moro cobraría coraçón e avría grant consolación. E por esta misma manera era el fecho del árabo con el labrador, por que la razón del rabí es nichil $^{92}$ [Cf. Ses. LVI].

Item, aprés ${ }^{93}$ dize una muy vana e muy fuera de razón, diziendo que, si el dicho del árabo fa/blava [fol. 261r] de tienpo pretérito, seguirse á que eran pruevas distintas ${ }^{94}$; e que por esso non se podría adaptar el dicho del dotor que dixo: «¿Qué vos lo cale provar por el árabo?; que testo claro es de Ysaý et caetera». A esto digo que le otorgo que son pruevas distintas la del árabo e de Ysaý, mas por esso ya non se adapta menos, ante más, e $<\mathrm{l}>{ }^{95}$ dicho del dotor; así como si un omne quisiese provar a otro que le devía cient florines, para lo qual oviesse traído buenos instrumentos ${ }^{96}$, e después quisiesse traer testimonios para provar aquello mismo, cierto es que le diría su abogado: «De va $<$ nament $>97$ te traballas a traer testimonios, pues buen instrumento tienes», aunque las pruevas de los testimonios e del instrumento son pruevas distintas. E ansí en el nuestro propósito e, non contrastante que el dicho profeta sia de futuro, el futuro dicto por el profeta a los que dan fe a la profecía les es tan cierto como lo que es ya passado [Cf. Ses. LVI].

\footnotetext{
${ }^{89}$ menor: del pueblo, inferior socialmente. $C f$. Marqués de Santillana, 1436: «e otros, languiendo, de fanbre morrían, / e sin esperança las gentes menores».

${ }^{90}$ plegará: llegará. Cf. Fuero de Teruel, ca. 1300: «Mas aquel que más aýna plegará al rey espere a su aduersario por tres días».

${ }^{91}$ estreito: estrecho. Cf. Vidal Mayor, ca. 1250: «es tenido de pensar estas cosas con estreito escodrynnamiento» .

${ }^{92}$ nichil: nada (lat. nihil). Cf. F. M. de Lando, 1414-a. 1435 «Si Dios aquí non remedia,/nichil es lo temporal».

${ }^{93}$ aprés: después. $C f$. J. Fernández de Heredia: «el dormir apres comer aprofita al cuerpo».

${ }^{94}$ Porque la profecía habla siempre del tiempo futuro. R. Astruch se había apoyado luego en la versión de Lamentaciones Rabbá para proponer una lectura figurada del relato; véase A. Pacios, ob. cit., II, p. 477.

${ }^{9} \mathrm{el}$ : Ms. es.

${ }^{96}$ instrumentos: documentos, contratos. Cf. Vidal Mayor: «fagan firmar aqueillos instrumentos con $\mathrm{sub}[\mathrm{s}]$ criptiones o con sieillos auténticos».

${ }^{97}$ de vanament: Ms. devantde; Actas lat. in vanum.
} 
E la metáfora e figura que el dicho rabí ha so $<\tilde{n}>$ ado $^{98}$, en la qual $<$ ocupa $>99$ a sus escriptura[s], digo que es escusado de responder a ella, pues es invención de su propia cabeça que non refunda en actoridat nin en razón; pero, por que más paresca el desvariamiento della, digo que quando dize en el comienço de la dicha figura que los dos bueyes significan la comunidat de Israel, la qual se conservava en la variedat de dos naturas de omnes, es a saber, / [fol. 261v] phariseos e omnes que solamente eran dado[s] a servicio de Dios, e otros omnes singulares que curavan de las cosas tenporales et caetera, esto todo omne veye que es figura muy inpropia, ca, como los bueyes entramos fuesen de una misma natura, ¿por qué razón ha de significar dos naturas distintas de omnes? E para que oviessen algunt color lo que el dicho rabí dize devieran seer un asno e un buey [...].

E más se siguiría de sus dichos que, como oy entre los judíos non sean aquellas dos naturas de omnes para que se pueda[n] juñir ${ }^{100}$, síguese que los bueyes nunca se junieran e el Massías nunca verná. / [fol. 262r] Todo lo otro que se sigue en la dicha figura es más adevinar que non razonar; e aun contiene en sí mentiras magnifiestas [...]. Pero si a posar figuras andamos, yo faré a la actoridat sobredicha consonante con las palabras del dotor. Que la que él á fecho se entiende el pueblo ebraico, que ansí lo clamó Malachías, c. $3^{\circ}$, do dizen: «Eritis vos terra desiderabilis», dicit Dominus [Mal 3,12]; iten, Deutero c. XXXII: Pars autem Domini populus eius Jacobo funiculus hered[it]atis eius [De 32,9]. E asemejólos a tierra porque la tierra es el más palpa $<$ tiv $>0^{101}$ e el más material de los alimentos. E así este vocablo come las cosas nuevas e la Ley santa justa las significac[i]ones materiales e la tenporalidat, e non curan res ${ }^{102}$ de lo spiritual.

E el judío que labrava en aquella tierra es significança de los sabios della clamados fariseos, por $<$ que $>^{103}$ los sabios han carga de custod[i]ar la gente e senbrarla de buenas virtudes, assí como el labrador el canpo. Los quales fariseos senblantes en aquel pueblo la dotrina clamada Talmud, en la qual possaron todas las cerimonias e régulas con que el pueblo devía ve[v]ir ${ }^{104}$. El qual labrador faría la dicha simiente mejançante ${ }^{105}$ dos bueyes que tenía el uno al cuello aquellos yugos significavan la ley e la dotrina/[fol. 262v] de aquella, que así la nonbró Jerónimo en la suya. Los quales dos bueyes significavan las dos copilaciones del Talmud, que la una se fizo en Jherusalem

\footnotetext{
${ }^{98}$ soñado: Ms. sonado; Actas lat. sompniavit.

${ }^{99}$ ocupa: Ms. oculpa; Actas lat. occupat

${ }^{100}$ juñir: unir, juntar. $C f$. F. Sayol, 1380-1385: «aquestas teulas farás ajustar e juñir las unas con las

${ }^{101}$ palpativo: Ms. palpaçio; Actas lat. palpativus.

${ }^{102}$ res: nada. $C f$. J. Fernández de Heredia: «no haprouecha res tomar cuydado».

${ }^{103}$ porque: Ms. por.

${ }^{104}$ vevir: Ms. venir; Actas lat. vivere.

${ }^{105}$ mejançante: mediante. Cf. Vidal Mayor:«el quoal [...] meyanant aqueilla soffriença»
} otras»». 
e la otra en Babilonia. E pueden significar los dos bueyes a Rabina e Rabasse, que fueron copiladores del Talmud ordenado por los dichos pfariseos. E asénblalos a bueyes porque en lo más de lo que fablaron bestialmente, non con razón fundada alguna, los dos bramidos de los bueyes significan dos naturas de bozes que fueron en el dicho Talmud: la una es palabras que vienen contra verdat e la santa fe cathólica; la otra, cosa que viene en confirmación de aquella.

El árabo que entendió aquellas otras bozes e declarava aquellas al judío es el predicador christiano, e intituléasse en este nonbre, «árabo», porque este nonbre es ebraico; se deriva de «cosa sabrosa» e «cosa muy plazentera» ${ }^{106}$. E así es: el predicador, con grant saber e con grant plazer, vos quiere declarar aquellas dos bozes que oye cridar ${ }^{107}$ a aquellos bueyes. Por la primera boz, la qual es las abominaciones e las cerimonias sinrazonables que crida el Talmud, les muestra que devedes desparellar ${ }^{108}$ los bueyes e desanpararlos, porque vuestro Santuario se destruye. Quiere dezir que por causa de aquello, vuestras ánimas se van a perder, cada ánima es la cosa más santa que es en el omne; e declaramos que siguiendo aquella boz tan érega ${ }^{109} \mathrm{e}$ tan malvada que es en el Talmud, el vuestro santuario, / [fol. 263r] es a saber, la ánima, pierda la gloria spiritual.

La segunda boz que cridan los dichos bueyes es muchas buenas anunciaciones que ha en el dicho Talmud, así como mostrar por diversas actoridades el tienpo del advenimiento del Massías e cómo devía nascer en Betlem [... ${ }^{110}$. Aquella boz segunda significa estas cosas que cridan aquellos dos bueyes por diversos logares del Talmud, segund que más largamente vos á seído mostrado en XII interrogaciones fechas en el processo. La dicha boz vos declara aqueste árabo e vos dize que significa el Massías que es venido, e que es en Betlem, e que ha nonbre Menahem, fijjo de Ezechías, mostrando lo que, mejançante aquesta boz, avredes consolación e fortaleza de Dios en vuestra ánimas, segund que se muestra por este vocablo «Menahem» e «Ezechías». E para fazer esto dirévos que enparelledes ${ }^{111}$ los bueyes, es a saber que consideredes bien todos los libros del Talmud uno $<$ e el $>^{112}$ del otro e tomedes todas las actoridades que tractan en esta materia e las conformedes bien / [fol. 263v] las unas con las otras. E trobaredes la verdat, de la qual se siguiría salvación de vuestras

${ }^{106}$ Entre las muchas acepciones de la raíz verbal ברע (' $R B$ ) se encuentra: «ser dulce, grato, agradable» (J. Targarona, ob. cit., p. 963).

${ }^{107}$ cridar: gritar, aquí «pregonar». Cf. Ordenación dada a [...] Zaragoza por el rey Fernando I, 1414: «fagan cridar publiccament [...] en la dita Ciudat».

${ }^{108}$ desparellar: desuncir, desaparejar. $C f$. J. Fernández de Heredia: «por tal que [...] tomándolo seguro e desparellándolo, vençiesse»».

109 érega: herética. $C f$. Actas lat.: «hereticam».

${ }^{110}$ Así como nacer de mujer virgen, ser Dios y hombre, dar Ley nueva y redimirnos por su Pasión.

111 enparelledes: emparejéis, unzáis. $C f$. J. Fernández de Heredia: «las senyorias, las quales vosotros [...] enparellades a los çielos».

${ }^{112}$ e el: Ms. del. Cf. Actas lat.: «libros unius Talmud et alterius» (A. Pacios, ob. cit., II, p. 493). 


\section{A. Alba Cecilia y C. Sainz de la Maza}

ánimas. E esta figura es consonante con las palabras de la dicha actoridad, e non la vuestra [Cf. Ses. LVI].

A la luz de los testimonios examinados, el «Cuento del buey que bramó» nos revela, pues, su destacado papel como protagonista del debate cristiano-judío acerca de los rasgos identificadores del Mesías prometido por la Escritura. La variedad de formulaciones en su traducción de las fuentes rabínicas al latín y al romance, su enunciación parcial, cuando así convenía, y la multiplicidad de funciones que se le adjudicaron en su aplicación a favor o en contra de los distintos argumentos mesiánicos de ambas partes, ejemplifican, con una intensidad solo comparable a la de muy pocas auctoritates bíblicas o rabínicas, el valor que, para la poética de la nueva polémica misionera de la Baja Edad Media, posee el género narrativo de las hagadot. Un género que, de modo un tanto paradójico, solo pudo asomarse a las lenguas vernáculas de la península gracias a una literatura -la de controversia oral y escrita- que perseguía, precisamente, la eliminación de lo que, en origen, esas mismas hagadot representaban para el judaísmo.

Recibido: 1/04/2015

Aceptado: 11/06/2015 


\title{
$\cos$
}

\section{EL «CUENTO DEL BUEY QUE BRAMÓ»: ENTRE EL JUDAÍSMO RABÍNICO Y EL CRISTIANISMO MILITANTE}

\begin{abstract}
RESUMEN: La incorporación de judíos conversos a las filas del cristianismo agresivamente misionero de la Baja Edad Media tuvo como consecuencia que una gran parte del material narrativo que, con fines didácticos y religiosos, se hallaba disperso en la Haggadá rabínica, fuera utilizado por estos nuevos cristianos para argumentar contra el judaísmo a partir de su propia tradición literaria y doctrinal. En este artículo seguiremos el rastro de uno de los relatos más utilizados en las discusiones sobre el Mesías, el que denominamos «Cuento del buey que bramó», en diversos testimonios orales y escritos de la polémica antijudía peninsular.
\end{abstract}

Palabras clave: Literatura rabínica. Cuentos. Polémica antijudía. Barcelona. Tortosa. Najmánides. Jerónimo de Santa Fe.

\section{The «Tale of the Bellowing Ox»: Between Rabbinic Judaism AND Combative Christianity}

ABstRAct: In the late Middle Ages, converted Jews enrolled into the aggressively missionary ranks of Christianity. As a result, a significant part of the narrative material that had been previously dispersed in the Rabbinical Haggadah for didactic and religious purposes was used by these new Christians in order to argue against Judaism on the basis of its own literary and doctrinal tradition. One of the most common stories used in discussions on the Messiah is the «Tale of the Bellowing Ox» (our name). This paper traces the path of the tale in various oral and written testimonies within the Peninsular anti-Jewish controversy.

Keywords: Rabbinic Literature. Tales. Anti-Jewish Polemics. Barcelona. Tortosa. Najmánides. Jerónimo de Santa Fe. 